\title{
Spatial patterns of some trace elements in four Swedish stream networks
}

\author{
J. Temnerud ${ }^{1,2}$, A. Düker ${ }^{1}$, S. Karlsson ${ }^{3}$, B. Allard ${ }^{3}$, K. Bishop ${ }^{1,4}$, J. Fölster ${ }^{1}$, and S. Köhler ${ }^{1}$ \\ ${ }^{1}$ Department of Aquatic Sciences and Assessment, Swedish University of Agricultural Sciences, Uppsala, Sweden \\ ${ }^{2}$ Swedish Meteorological and Hydrological Institute, Research Department, Norrköping, Sweden \\ ${ }^{3}$ Man-Technology-Environment Research Centre, Örebro University, Örebro, Sweden \\ ${ }^{4}$ Department of Earth Sciences, Uppsala University, Uppsala, Sweden
}

Correspondence to: J. Temnerud (johan.temnerud@slu.se)

Received: 27 March 2012 - Published in Biogeosciences Discuss.: 15 May 2012

Revised: 4 January 2013 - Accepted: 18 January 2013 - Published: 1 March 2013

\begin{abstract}
Four river basins in southern Sweden, with catchment sizes from 0.3 to $127 \mathrm{~km}^{2}$ (median 1.9), were sampled in October 2007. The 243 samples were analysed for 26 trace elements (Ag, As, Au, Ba, Be, Bi, Cd, Co, Cr, Cu, Ga, Ge, In, $\mathrm{La}, \mathrm{Li}, \mathrm{Mo}, \mathrm{Ni}, \mathrm{Pb}, \mathrm{Sb}, \mathrm{Se}, \mathrm{Sn}, \mathrm{Tl}, \mathrm{Ti}, \mathrm{U}, \mathrm{V}$ and $\mathrm{Zn}$ ) to identify spatial patterns within drainage networks. The range and median of each element were defined for different stream orders, and relationships to catchment characteristics, including deposition history, were explored. The sampling design made it possible to compare the differences along 40 stream reaches, above and below 53 stream junctions with 107 tributaries and between the 77 inlets and outlets of 36 lakes. The largest concentration differences (at reaches, junctions and lakes) were observed for lakes, with outlets usually having lower concentration compared to the inlets for As, $\mathrm{Ba}$, $\mathrm{Be}, \mathrm{Bi}, \mathrm{Cd}, \mathrm{Co}, \mathrm{Cr}, \mathrm{Ga}, \mathrm{Ge}, \mathrm{Ni}, \mathrm{Pb}, \mathrm{Sn}, \mathrm{Ti}, \mathrm{Tl}, \mathrm{U}, \mathrm{V}$ and $\mathrm{Zn}$. Significantly lower concentrations were observed for $\mathrm{Cd}$ and Co when comparing headwaters with downstream sites in each catchment. Common factor analysis (FA) revealed that $\mathrm{As}, \mathrm{Bi}, \mathrm{Cr}, \mathrm{Ga}, \mathrm{Ge}, \mathrm{Tl}$ and $\mathrm{V}$ co-vary positively with $\mathrm{Al}$, $\mathrm{Fe}$ and total organic carbon (TOC) and negatively with La, $\mathrm{Li}$ and $\mathrm{pH}$. The strong removal of a large number of trace elements when passing through lakes is evident though in the FA, where lake surface coverage plots opposite to many of those elements. Forest volume does not respond in a similar systematic fashion and, surprisingly, the amount of wetland does not relate strongly to either Fe or TOC at any of the rivers. A better understanding of the quantitative removal of organic carbon and iron will aid in understanding trace element fluxes from landscapes rich in organic matter and iron.
\end{abstract}

\section{Introduction}

The importance of headwaters as a resource for biodiversity and human welfare is increasingly recognised (Lowe and Likens, 2005; Bishop et al., 2008). One reason is that headwaters make up most of the watercourse length and hence provide a large proportion of water and solutes to downstream sites (Alexander et al., 2007). For example, streams with catchment size $<2 \mathrm{~km}^{2}$ make up approximately $80 \%$ of the total length of all perennial watercourses in Sweden (Nisell et al., 2007). Headwaters also provide the most direct indication of what the terrestrial landscape is contributing to surface waters before in-stream and in-lake processes begin to alter the chemistry of runoff water.

It is widely known that the variability in water quality changes with catchment size. Typically small watercourses show the highest variability in both space (Wolock et al., 1997; Temnerud and Bishop, 2005) and time (Nagorski et al., 2003; Buffam et al., 2007). Significant efforts have been made to quantify the variability of headwaters (e.g. Hutchins et al., 1999; Smart et al., 2001; Likens and Buso, 2006).

The distribution and concentration of a large number of trace elements in the landscape is useful in a variety of ways. Since increasing trace element use in the technosphere is increasing their spread in the environment, it is important to define current levels and patterns against which future changes can be judged (Grahn et al., 2006; Karlsson et al., 2006; Reimann et al., 2009). Documentation of trace elements can also help in defining controls on the heterogeneity of terrestrial exports to surface waters (Lofts and Tipping, 2000), 




Fig. 1. Map of Sweden with the four rivers included: Danshytteån (R. D.), Getryggsån (R. G.), Anråse å (R. A.) and Lugnån (R. L.). The black dots are sampled sites. For stream junctions one dot could indicate that samples were taken upstream and downstream of the junction. $\mathrm{O}$ indicates the outlets of the rivers.

lake processes (Johansson et al., 2001; Taillefert and Gaillard, 2002) and downstream transformations that can be of value in managing land use for water quality (Reimann et al., 2009). Quantifying landscape variation and potential drivers of water quality is relevant for management of forestry practices and nutrient leaching.

Some studies estimating the spatial variability of trace elements in Scandinavia, at spatial scales from $10-100 \mathrm{~km}^{2}$, have been published (Tarvainen et al., 1997; Edén et al., 1999; Andersson et al., 2006; Dahlqvist et al., 2007; Reimann et al., 2009; Lidman et al., 2012). The novel focus in this study is on headwaters, $<2 \mathrm{~km}^{2}$, in combination with larger streams in the channel network of complete rivers, including the lakes embedded in those networks.

The boreal Northern Hemisphere is rich in lakes, and they need to be accounted for when spatial patterns of stream networks are evaluated. Lakes can significantly change the concentration of total organic carbon (TOC), $\mathrm{Al}, \mathrm{Fe}$ and trace elements in streams, as the water velocity decreases and water depth increases which allows biological, chemical and physical processes to proceed further than they can in run- ning waters (Drever, 1997). Examples of such processes are; flocculation (von Wachenfeldt and Tranvik, 2008) and sedimentation of particles, changes in $\mathrm{pH}$ and redox potential, all of which have been described chemically (Honeyman and Santschi, 1988; Lofts and Tipping, 2000). Lakes in the Swedish boreal landscape usually have higher buffering capacity and $\mathrm{pH}$ at the outlet than at the inlets (Meili, 1992).

The aim of this study is to characterize the spatial variability of a range of trace elements $\mathrm{Ag}, \mathrm{As}, \mathrm{Au}, \mathrm{Ba}, \mathrm{Be}, \mathrm{Bi}, \mathrm{Cd}$, $\mathrm{Co}, \mathrm{Cr}, \mathrm{Cu}, \mathrm{Ga}, \mathrm{Ge}$, In, $\mathrm{La}, \mathrm{Li}, \mathrm{Mo}, \mathrm{Ni}, \mathrm{Pb}, \mathrm{Sb}, \mathrm{Se}, \mathrm{Sn}, \mathrm{Tl}$, $\mathrm{Ti}, \mathrm{U}, \mathrm{V}$ and $\mathrm{Zn}$ ) entering the drainage network in the headwaters of four river networks varying in land use, landscape type, geographical location and impact by acid rain. The downstream changes in concentrations are also quantified at the river outlet for an accumulated area of between 0.3 and $127 \mathrm{~km}^{2}$. In each of these rivers, Swedish long-term monitoring sites exist. This makes it possible to locate the sampling occasions in the long-term variation of other water chemistry parameters of importance for trace elements including $\mathrm{pH}$, $\mathrm{Fe}, \mathrm{Al}$ and TOC. The main hypothesis (1) is that trace elements and TOC (as well as $\mathrm{Al}$ and $\mathrm{Fe}$ ) show the same general pattern of catchment outputs and downstream changes. Trace element concentration changes in downstream areas would then be mainly due to TOC sources and sinks, with the position and volume of lakes being a major factor since TOC (in combination with $\mathrm{Al}$ and $\mathrm{Fe}$ ) is the main carrier of trace elements (Lyvén et al., 2003). Furthermore, we expect (2) that a number of elements show significant co-variation due to their geochemical resemblance. In addition, we test (3) if the history of the acid deposition or sea salt inputs may impact trace element mobilisation at the landscape level.

\section{Methods}

\subsection{Sampling approach}

The synoptic surveys used in this study were designed to provide a snapshot of the water chemistry in the stream networks (Fig. 1 and Table 1). All sampling was carried out in October 2007 over a one to three day period per catchment when the weather was stable. A total of 243 grab samples were taken, and the majority of the samples were taken at headwaters (Fig. 2 and Table 1), which in this study are defined as sites with a catchment size of $<2 \mathrm{~km}^{2}$.

\subsection{Study area}

The four studied rivers, Anråse å (R. A.), Danshytteån (R. D.), Getryggsån (R. G.), and Lugnån (R. L.), are located in southern Sweden (Fig. 1 and Table 1). The rivers include four existing Swedish long-term monitoring sites; Asa Experimental Forest and Research Station in R. L., Buskbäcken in R. G., Gårdsjön in R. A. and Kindla in R. D. The dominant vegetation type is coniferous forest (> $80 \%)$, mainly Picea abies, Norway spruce, on till soils (Table 1). Mires 
Table 1. Map material for each catchment, median with 5th and 95th percentiles in parentheses. Outlet runoff is the daily HYPE modelled runoff during sampling compared to percentiles (perc) for October 1990-2010. For more details, see the Methods section.

\begin{tabular}{|c|c|c|c|c|}
\hline & Anråse å (R. A.) & Lugnån (R. L.) & Danshytteån (R. D.) & Getryggsån (R. G.) \\
\hline Outlet latitude (N) and longitude (E) & $58^{\circ} 01^{\prime}, 11^{\circ} 51^{\prime}$ & $57^{\circ} 06^{\prime}, 14^{\circ} 48^{\prime}$ & $59^{\circ} 42^{\prime}, 15^{\circ} 05^{\prime}$ & $59^{\circ} 48^{\prime}, 15^{\circ} 17^{\prime}$ \\
\hline Sampling dates in October 2007 & $16-18$ & $23-25$ & $9-10$ & 10 \\
\hline Total sites, $n$ & 90 & 64 & 55 & 34 \\
\hline Altitude (m a.s.l.) & $89(14 / 138)$ & $206(167 / 236)$ & $206(148 / 293)$ & $279(201 / 336)$ \\
\hline Catchment size $\left(\mathrm{km}^{2}\right)$ & $2.0(0.13 / 35)$ & $3.4(0.31 / 78)$ & $1.2(0.08 / 62)$ & $1.1(0.08 / 33)$ \\
\hline Outlet size $\left(\mathrm{km}^{2}\right)$ & 86 & 127 & 80 & 36 \\
\hline Outlet altitude (m a.s.1.) & 12 & 166 & 122 & 182 \\
\hline Outlet runoff $\left(\mathrm{m}^{3} \mathrm{~s}^{-1}\right)$ & $0.33^{20-30 \text { perc }}$ & $0.81^{70-80 \text { perc }}$ & $0.25^{30-40 \text { perc }}$ & $0.13^{50-40 \text { perc }}$ \\
\hline Headwaters (HW), $n$ & 45 & 26 & 34 & 21 \\
\hline Stream reaches, $n$ & 13 & 10 & 9 & 8 \\
\hline Distance between reaches sites $(\mathrm{km})$ & $1.6(0.6 / 7)$ & $2.4(0.4 / 3.7)$ & $1.1(0.1 / 2.0)$ & $0.4(0.1 / 2.8)$ \\
\hline Stream junctions, $n$ & 25 & 9 & 11 & 8 \\
\hline Distance between junctions sites (m) & $270(63 / 1390)$ & $227(97 / 1886)$ & $192(45 / 1253)$ & $128(39 / 2818)$ \\
\hline Lakes, $n$ & 12 & 15 & 4 & 5 \\
\hline Distance to lake outlet $(\mathrm{km})$ & $11(6 / 16)$ & $14(2 / 20)$ & $11(9 / 17)$ & $10(3 / 14)$ \\
\hline $\begin{array}{l}\text { Lake outlet compared to the end } \\
\text { of the stream branch }(\%)\end{array}$ & $80(33 / 92)$ & $88(7 / 96)$ & $65(51 / 97)$ & $61(21 / 83)$ \\
\hline Stream length to sites $(\mathrm{km})$ & $10(4 / 16)$ & $16(6 / 21)$ & $14(10 / 17)$ & $14(3 / 16)$ \\
\hline Stream density $\left(\mathrm{km}^{2} \mathrm{~km}^{-1}\right)$ & $0.43(0.2 / 1.6)$ & $1.3(0.5 / 5.3)$ & $0.61(0.2 / 1.8)$ & $0.47(0.2 / 1.2)$ \\
\hline \multicolumn{5}{|l|}{ Land use map (\%) } \\
\hline Lake surface coverage & $4.7(0.0 / 20)$ & $3.9(0.0 / 19)$ & $0.2(0.0 / 10)$ & $0.3(0.0 / 20)$ \\
\hline Urban & $0.0(0.0 / 0.3)$ & 0 & 0 & $0.0(0.0 / 0.9)$ \\
\hline Forest & $80(65 / 95)$ & $80(69 / 94)$ & $91(83 / 100)$ & $89(66 / 99)$ \\
\hline Wetland & $7.3(0.0 / 17)$ & $4.7(0.0 / 24$ & $4.2(0.0 / 12)$ & $5.1(0.0 / 26)$ \\
\hline Open land & $1.3(0.0 / 5.4)$ & $3.1(0.0 / 7.6)$ & $0.8(0.0 / 5.3)$ & $1.3(0.0 / 4.3)$ \\
\hline Pasture & $0.6(0.0 / 6.4)$ & $2.4(0.0 / 6.9)$ & $0.0(0.0 / 1.0)$ & $0.0(0.0 / 0.5)$ \\
\hline Arable fields & $0.0(0.0 / 16)$ & $2.8(0.0 / 17)$ & $0.0(0.0 / 1.4)$ & $0.0(0.0 / 1.1)$ \\
\hline \multicolumn{5}{|l|}{ CORINE (\%) } \\
\hline Solitary houses & $0(0 / 0.3)$ & 0 & 0 & 0 \\
\hline Industrial & $0(0 / 0.3)$ & 0 & 0 & 0 \\
\hline Camping & 0 & 0 & 0 & $0(0 / 0.4)$ \\
\hline Arable land & $0(0 / 20)$ & $5.2(0 / 17)$ & $0(0 / 7.6)$ & $0(0 / 1.0)$ \\
\hline Pastures & $1.2(0 / 9.1)$ & $3.3(0.0 / 8.6)$ & $0(0 / 0.5)$ & $0(0 / 1.2)$ \\
\hline Broad-leaved forest not on mires & $0.8(0 / 18)$ & $3.8(0.0 / 14)$ & $1.7(0 / 8.4)$ & $0(0 / 2.0)$ \\
\hline Broad-leaved forest on mires & 0 & $0(0 / 0.2)$ & $0(0 / 1.2)$ & $0(0 / 0.4)$ \\
\hline Coniferous forest on lichen-dominated areas & $0(0 / 0.4)$ & $0(0 / 0.1)$ & $0.8(0 / 7.6)$ & $6.9(0.6 / 16)$ \\
\hline Coniferous forest $5-15 \mathrm{~m}$ & $18(6.5 / 41$ & $9.1(1.8 / 22)$ & $16(0 / 31)$ & $19(8.7 / 46)$ \\
\hline Coniferous forest $>15 \mathrm{~m}$ & $42(16 / 68)$ & $47(23 / 71)$ & $45(9.1 / 91)$ & $27(15 / 57)$ \\
\hline Coniferous forest on mires & $2.0(0 / 8.6)$ & $3.6(0 / 15)$ & $1.5(0 / 7.6)$ & $0.9(0 / 8.9)$ \\
\hline Coniferous forest on open bedrock & $0.1(0 / 5.5)$ & 0 & $0(0 / 0.3)$ & 0 \\
\hline Mixed forest not on mires & $8.7(0 / 21)$ & $5.3(0 / 11)$ & $8.9(0 / 23)$ & $4.3(0 / 16)$ \\
\hline Mixed forest on mires & $0(0 / 0.1)$ & $0(0 / 0.8)$ & $0(0 / 0.2)$ & $0(0 / 0.2)$ \\
\hline Clear-felled areas & $5.6(0 / 15)$ & $8.5(0.5 / 21)$ & $13(0 / 31)$ & $22(0.5 / 47)$ \\
\hline Younger forest & $0(0 / 1.5)$ & $2.8(0 / 7.4)$ & $3.0(0 / 12)$ & $2.2(0.0 / 9.7)$ \\
\hline Inland marshes & 0 & $0(0 / 0.2)$ & $0(0 / 0.5)$ & $0(0 / 0.1)$ \\
\hline Wet mires & 0 & $0(0 / 0.1)$ & 0 & 0 \\
\hline Other mires & $3.0(0 / 11)$ & $0(0 / 2.2)$ & $0(0 / 5.4)$ & $3.6(0 / 17)$ \\
\hline Lakes and ponds, open surface & $4.4(0 / 20)$ & $4.1(0 / 20)$ & $0(0 / 11)$ & $0(0 / 20)$ \\
\hline Lakes and ponds, surface being grown over & $0(0 / 0.2)$ & 0 & $0(0 / 0.1)$ & 0 \\
\hline
\end{tabular}


Table 1. Continued.

\begin{tabular}{|c|c|c|c|c|}
\hline & Anråse å (R. A.) & Lugnån (R. L.) & Danshytteån (R. D.) & Getryggsån (R. G.) \\
\hline \multicolumn{5}{|l|}{ kNN database } \\
\hline The age of the forest stand (yr) & $55(45 / 74)$ & $54(43 / 65)$ & $56(39 / 77)$ & $50(32 / 79)$ \\
\hline Average height of the forest (m) & $16(12 / 19)$ & $16(13 / 19)$ & $14(10 / 19)$ & $12(7.0 / 16)$ \\
\hline $\operatorname{Birch}^{B}\left(m^{3} h^{-1}\right)$ & $17(12 / 22)$ & $13.6(10.4 / 19$ & $11.9(4.2 / 20)$ & $7.5(2.5 / 16)$ \\
\hline Spruce $^{\mathrm{S}}\left(\mathrm{m}^{3} \mathrm{ha}^{-1}\right)$ & $99(49 / 167)$ & $119.8(71.5 / 163$ & $73.8(40.1 / 130)$ & $41.3(20.9 / 63)$ \\
\hline $\operatorname{Pine}^{\mathrm{P}}\left(\mathrm{m}^{3} \mathrm{ha}^{-1}\right)$ & $61(48 / 75)$ & $55.4(34.1 / 72)$ & $74.5(45.4 / 109)$ & $73.6(48.0 / 114)$ \\
\hline $\mathrm{Oak}^{\mathrm{O}}\left(\mathrm{m}^{3} \mathrm{ha}^{-1}\right)$ & $1.3(0.1 / 6.5)$ & $3.8(1.6 / 6.8)$ & $0.1(0 / 0.7)$ & $0(0 / 0.2)$ \\
\hline Other forest $\left(\mathrm{m}^{3} \mathrm{ha}^{-1}\right)$ & $4.7(1.4 / 13)$ & $5.3(3.1 / 10)$ & $3.3(0.8 / 8.1)$ & $2.0(0.3 / 5.8)$ \\
\hline Forest volume, total $\left(\mathrm{m}^{3} \mathrm{ha}^{-1}\right)$ & $188(127 / 256)$ & $199(151 / 248)$ & $166(120 / 241)$ & $129(79 / 181)$ \\
\hline \multicolumn{5}{|l|}{ Soil type $(\%)$} \\
\hline Organic & $16(0 / 29)$ & $2.1(0 / 24)$ & $4.4(0 / 24)$ & $22(2.6 / 77)$ \\
\hline Clay & $2.9(0 / 23)$ & $0(0 / 0.1)$ & $0.0(0 / 0.2)$ & $0(0 / 0.1)$ \\
\hline Silt & $0(0 / 5.3)$ & 0 & 0 & 0 \\
\hline Sand & $1.2(0 / 14$ & 0 & $0(0 / 1.8)$ & 0 \\
\hline Glacifluvial & $0(0 / 5.1$ & $0(0 / 0.9)$ & 0 & $0(0 / 0.1)$ \\
\hline Till & $2.7(0 / 7.1)$ & $70(54 / 93)$ & $77(42 / 100)$ & $63(0 / 81)$ \\
\hline Thin soil cover & 0 & 0 & 0 & $0(0 / 97)$ \\
\hline Bare rock & $64(47 / 79)$ & $15(2.6 / 36)$ & $7.1(0 / 46)$ & $2.2(0 / 5.5)$ \\
\hline Lake surface coverage & $5.7(0 / 19)$ & $3.7(0 / 21)$ & $0.3(0 / 13)$ & $0(0 / 22)$ \\
\hline
\end{tabular}

For CORINE classes a short-name was given; for details see http://www.eea.europa.eu/publications/COR0-landcover. ${ }^{\mathrm{B}}$ is Betula spp., ${ }^{\mathrm{S}}$ is Norway spruce (Picea abies), ${ }^{\mathrm{P}}$ is Scots pine (Pinus silvestris) and ${ }^{\mathrm{O}}$ is English oak (Quercus robur).

and small humic lakes made up most of the remaining parts of the catchments, while the proportions of agricultural and developed areas were minimal $(<1 \%)$. The mean annual air temperature (1961-1990) in the catchments ranged from $7^{\circ} \mathrm{C}$ in the southernmost catchment, R. A., to $4{ }^{\circ} \mathrm{C}$ in the northernmost catchment, R. G. Mean annual rainfall and runoff ranged from 1050 and $550 \mathrm{~mm}$ at $\mathrm{R}$. A. to 750 and $250 \mathrm{~mm}$ at R. L., respectively. Daily runoff for 1990-2010 at each river outlet was modelled based on HYPE (Lindström et al., 2010) data downloaded 25 January 2012 from http://vattenweb.smhi.se (HYPE version 3.5.3 using catchment typology SVAR 2010:2). The runoff were normalised according to (daily $Q$ in 2007 - median $Q$ for the whole period 1990-2010)/ interquartile range of $Q$ for the whole period 1990-2010 (Fig. 2). Runoff at the time of sampling in October 2007 was compared to percentiles based on October 1990-2010 (Table 1). Marine impacts, such as chloride deposition, were largest at $\mathrm{R}$. A. and in decreasing order R. L., R. D. and R. G. Medians for bulk deposition of chloride $\left[\mathrm{mEq} \mathrm{L}^{-1}\right.$ ] during 2007 were 0.053 (Gårdsjön), 0.020 (Aneboda) and 0.012 (Kindla) (Löfgren et al., 2011) (in the cited work Gårdsjön is a site inside R. A., Aneboda is approximately $50 \mathrm{~km}$ south-west of R. L. and Kindla is inside R. D.). Liming activities have historically taken place in all rivers, to the largest extent in R. A. and then in decreasing order R. L., R. D. and R. G. (Temnerud et al., 2009; Fölster et al., 2011). For R. G. no liming occurred in 2005-2007, and in the other three rivers we know that liming took place during 2005-2007 (Table 2 in Temnerud et al., 2009), which also could affect downstream sites. The percentage of estimated sites affected by liming in R. A. was $69 \%$, in R. D. was $17 \%$ and in R. L. $56 \%$. When estimating the degree of acidification in 2007, using metaMAGIC (Erlandsson et al., 2008), no sites in R. G. were considered to be acidified, $4 \%$ of the sites in R. D., $28 \%$ of the sites in R. L. and $38 \%$ of the sites in R. A. This estimation is in accordance with the pattern of sulphur deposition over the country that is highest in the south-west and decreasing in both the north and the east (Moldan et al., 2004).

The R. A. catchment has larger median coverage of lake surface coverage and wetlands than the other three river catchments (Table 1), and a more heterogeneous soil mostly consisting of bare rock, while the other catchments were dominated by till. The arable land areas were small, with the largest portion in R. L., which also had the largest volume of forest. The R. D. catchment has the smallest percentage of lake surface coverage, and the forest has equal volumes of pine and spruce. The smallest catchment, R. G., has the highest percentage of wetlands and the forest is dominated by pine. For other details, see Temnerud et al. (2009).

\subsection{Chemical analyses}

After collection, all water samples were kept dark and cool until they were analysed. Total organic carbon (TOC) was measured as $\mathrm{CO}_{2}$ after combustion using a Shimadzu TOC$\mathrm{VPCH}$ analyser, after acidification and sparging to remove 
inorganic carbon. It has previously been shown that dissolved organic carbon (DOC) and TOC differ on average by less than $5 \%$ (Ivarsson and Jansson, 1994; Köhler, 1999), so TOC is essentially identical to DOC in these waters (see also Gadmar et al., 2002). Total nitrogen $(\mathrm{N})$ is the sum of Kjeldahl nitrogen and of nitrite and nitrate analysed according to the standard SS-EN ISO 13395. Total phosphorous (P) was analysed according to SS-EN ISO 6878.

Unfiltered samples for ICP-OES analysis (aluminium (Al), barium $(\mathrm{Ba})$, calcium $(\mathrm{Ca})$, iron $(\mathrm{Fe})$, potassium $(\mathrm{K})$, lanthanum $(\mathrm{La})$, magnesium $(\mathrm{Mg})$, manganese $(\mathrm{Mn})$, sodium $(\mathrm{Na})$, sulphur (S), silicon $(\mathrm{Si})$, strontium $(\mathrm{Sr})$ and titanium (Ti)) were preserved with concentrated nitric acid (redistilled from reagent grade acid) to a final concentration of $0.15 \mathrm{M}$. These samples were analysed for silver $(\mathrm{Ag})$, arsenic $(\mathrm{As})$, gold $(\mathrm{Au})$, beryllium $(\mathrm{Be})$, bismuth $(\mathrm{Bi})$, cadmium $(\mathrm{Cd})$, cobalt $(\mathrm{Co})$, chromium $(\mathrm{Cr})$, copper $(\mathrm{Cu})$, gallium $(\mathrm{Ga})$, germanium (Ge), indium (In), lithium (Li), molybdenum (Mo), nickel $(\mathrm{Ni})$, lead $(\mathrm{Pb})$, antimony $(\mathrm{Sb})$, selenium $(\mathrm{Se})$, tin $(\mathrm{Sn})$, thallium $(\mathrm{Tl})$, uranium $(\mathrm{U})$, vanadium $(\mathrm{V})$ and zinc (Zn) with an ICP-MS (Agilent 4500) equipped with an ultrasonic nebulizer (U-6000AT+, CETAC). Samples for anion (sulphate $\left(\mathrm{SO}_{4}\right)$ and chloride $(\mathrm{Cl})$ ) analysis were stored frozen until analysed on a Dionex ion chromatograph system. The typical precision in anion and cation analyses based on measurements of certified standards was better than $2 \%$. For limit of detection (LOD), 3 times the standard deviation of the blank was used for the trace elements, see Table 2. Acid neutralizing capacity (ANC) was calculated as the difference between strong base cations and strong inorganic acid anions (Köhler et al., 2001). ICP-OES and anion analysis were performed at the Department of Geological Sciences, Stockholm University, ICP-MS and TOC at Örebro University, and $\mathrm{N}, \mathrm{P}$ and $\mathrm{pH}$ at Vattenlaboratoriet, Uppsala Municipality, respectively.

\subsection{Map material}

To relate trace elements to catchment character, we used land use maps on the scale 1:100000 (SNLS, 2002) and soil maps, along with the kNN database of vegetation that contains forestry variables estimated from Landsat 2000 satellite photos (Reese et al., 2003) (Table 1). The variable "organic soil type" is referred to as "peat" in this study. A land use data set called CORINE, provided by the European Environment Agency, was also used (EEA, 2002). Digital soil data were available for R. A. (SGU, 2001). For the other catchments, photographs of these soil maps, with GIS coordinates, were digitalised manually: R. L. year 1876 and scale $1: 200000$, R. D. year 1879 and scale $1: 50000$, and R. G. year 1930 and scale $1: 50000$ and for a small part $(\sim 10 \%)$ map from year 1872 and scale $1: 50000$. The percentages of each variable on each catchment from the land use and soil maps were used in the modelling. In addition to the data read directly from each map, three variables were calculated from the map in- formation: stream length $(\mathrm{m})$, drainage density $\left(\mathrm{km}^{-1}\right)$, and altitude (m). Drainage density is the ratio of the total length of streams within a catchment to the total area of the catchment. In Swedish glacial till catchments, the Quaternary soils usually have larger impact on stream water chemistry than the bed rock geology (Lax et al., 1995; Lax, 2005).

\subsection{Statistical analysis}

In order to estimate the variability of water chemistry between catchments, robust coefficient of variation (CV) was used. Robust $\mathrm{CV}=100 \times$ normalised $\mathrm{IQR} /$ median, where IQR is the interquartile range (75-25 percentile) and normalised IQR is IQR multiplied by 0.7413 (PTA, 2006). The factor 0.7413 makes IQR comparable to standard deviation; if the distribution is normal, normalised IQR values would equal standard deviation. Since the data are not normally distributed (tested using one-sample Kolmogorov-Smirnov test) and there are generally few samples, normalised IQR was used. A Piper diagram was used to evaluate the differences in major cations and anions (Piper, 1944); the diagram was made using the software GW_Chart version 1.23.3.0 for MS Windows (Winston, 2000).

Common factor analysis (FA), also called principal axis factoring, was performed to check for latent structures in trace elements, major chemistry and physical parameters using the oblique (non-orthogonal) rotation method Oblimin $(\delta=0)$ and Kaiser normalisation (SPSS for Windows v19.0). The Kaiser-Meyer-Olkin (KMO) measure of sampling adequacy tests whether the partial correlations among variables are small. KMO should be greater than 0.6 in order to make FA valid to perform. Another indicator of the strength of the relationship among variables is Bartlett's test of sphericity, which is used to test the null hypothesis that the variables in the correlation matrix are uncorrelated. When the significance level is small enough to reject the hypothesis ( $p<0.0001)$, the relationship among variables is strong, and FA can be conducted. In FA the variance of a single variable is decomposed into common variance that is shared by other variables included in the model and unique variance that is specific to a particular variable (Gauch, 1982). Principal component analysis (PCA), a similar multivariate procedure, considers the total variance and makes no distinction between common and unique variance (Gauch, 1982). Oblique rotation allows the factors to correlate, and if the factors are truly uncorrelated, orthogonal and oblique rotation produce similar results (Costello and Osborne, 2005).

Chloride was omitted from all FA analyses since it made the matrix indefinite, i.e. the eigenvalues were not positive. Of all variables in Table 1, the following were used: altitude, forest volume, lake surface, drainage density, forest, wetland, open fields (arable, pasture and open field), because the other variables made the matrix indefinite or gave $\mathrm{KMO}<0.6$. Likewise, F, N, Na and P were omitted for R. D., and Ca, $\mathrm{F}, \mathrm{K}, \mathrm{Mg}, \mathrm{Mn}, \mathrm{N}, \mathrm{Na}, \mathrm{P}$, and $\mathrm{SO}_{4}$ for R. G., respectively. 
Table 2. Chemistry results for each catchment. Median with 5 th and 95 th percentiles in parentheses. $\mathrm{U}$ is units, where $n$ is ng $\mathrm{L}^{-1}, \mu$ is $\mu \mathrm{g} \mathrm{L}^{-1}, m$ is $\mathrm{mg} \mathrm{L}^{-1}$ and eq is $\mu \mathrm{eq} \mathrm{L}^{-1}$. LOD is limit of detection for trace elements. All is the average of all catchments, median and robust coefficient of variation $(\mathrm{CV})$. Bold numbers are significant $(\alpha<0.05$ and $1-\beta>0.80)$ difference between headwaters and downstream, where " + " indicate higher concentration in watercourses $>2 \mathrm{~km}^{2}$, bold without sign denotes a decrease.

\begin{tabular}{|c|c|c|c|c|c|c|c|c|}
\hline $\mathrm{C}$ & $\mathrm{U}$ & LOD & R. A. & R. L. & R. D. & R. G. & All & Europe median* \\
\hline $\mathrm{pH}$ & & & $\begin{array}{l}+6.9 \\
(4.3 / 7.2)\end{array}$ & $\begin{array}{l}6.5 \\
(5.1 / 7.0)\end{array}$ & $\begin{array}{l}5.9 \\
(4.5 / 6.7)\end{array}$ & $\begin{array}{l}+5.3 \\
(4.0 / 6.7)\end{array}$ & $\begin{array}{l}6.4 \\
17\end{array}$ & 7.7 \\
\hline ANC & eq & & $\begin{array}{l}189 \\
(-92 / 457)\end{array}$ & $\begin{array}{l}260 \\
(89 / 397)\end{array}$ & $\begin{array}{l}141 \\
(-19 / 211)\end{array}$ & $\begin{array}{l}+99 \\
(40 / 188)\end{array}$ & $\begin{array}{l}165 \\
76\end{array}$ & n.a. \\
\hline TOC & $m$ & & $\begin{array}{l}8.2 \\
(4.1 / 17)\end{array}$ & $\begin{array}{l}19 \\
(6.5 / 40)\end{array}$ & $\begin{array}{l}15 \\
(8.2 / 43)\end{array}$ & $\begin{array}{l}16 \\
(6.6 / 50)\end{array}$ & $\begin{array}{l}13 \\
69\end{array}$ & 4.99 \\
\hline $\mathrm{Cl}$ & & & $\begin{array}{l}13 \\
(11 / 21)\end{array}$ & $\begin{array}{l}6.3 \\
(5.1 / 7.6)\end{array}$ & $\begin{array}{l}2.5 \\
(2.0 / 12)\end{array}$ & $\begin{array}{l}2.2 \\
(1.5 / 3.8)\end{array}$ & $\begin{array}{l}6.3 \\
113\end{array}$ & 8.81 \\
\hline $\mathrm{F}$ & & & $\begin{array}{l}0.046 \\
(0.031 / 0.10)\end{array}$ & $\begin{array}{l}0.14 \\
(0.097 / 0.24)\end{array}$ & $\begin{array}{l}0.086 \\
(0.055 / 0.14)\end{array}$ & $\begin{array}{l}0.14 \\
(0.092 / 0.20)\end{array}$ & $\begin{array}{l}0.10 \\
60\end{array}$ & 0.10 \\
\hline $\mathrm{SO}_{4}$ & & & $\begin{array}{l}3.8 \\
(2.2 / 7.1)\end{array}$ & $\begin{array}{l}4.2 \\
(2.2 / 6.4)\end{array}$ & $\begin{array}{l}2.5 \\
(1.2 / 4.2)\end{array}$ & $\begin{array}{l}+1.8 \\
(0.7 / 2.8)\end{array}$ & $\begin{array}{l}3.4 \\
41\end{array}$ & 16.1 \\
\hline $\mathrm{Al}$ & & & $\begin{array}{l}0.22 \\
(0.087 / 0.59)\end{array}$ & $\begin{array}{l}0.29 \\
(0.064 / 0.61)\end{array}$ & $\begin{array}{l}0.43 \\
(0.12 / 1.1)\end{array}$ & $\begin{array}{l}0.36 \\
(0.085 / 0.68)\end{array}$ & $\begin{array}{l}0.31 \\
65\end{array}$ & 0.018 \\
\hline $\mathrm{Ca}$ & & & $\begin{array}{l}5.4 \\
(0.66 / 9.8)\end{array}$ & $\begin{array}{l}4.7 \\
(1.9 / 7.5)\end{array}$ & $\begin{array}{l}2.1 \\
(0.49 / 3.2)\end{array}$ & $\begin{array}{l}+1.4 \\
(0.75 / 3.2)\end{array}$ & $\begin{array}{l}3.2 \\
82\end{array}$ & 40.2 \\
\hline $\mathrm{Fe}$ & & & $\begin{array}{l}0.29 \\
(0.058 / 1.0)\end{array}$ & $\begin{array}{l}0.99 \\
(0.15 / 2.9)\end{array}$ & $\begin{array}{l}0.85 \\
(0.28 / 3.2)\end{array}$ & $\begin{array}{l}1.1 \\
(0.095 / 3.3)\end{array}$ & $\begin{array}{l}0.67 \\
107\end{array}$ & 0.067 \\
\hline K & & & $\begin{array}{l}0.50 \\
(0.23 / 1.9)\end{array}$ & $\begin{array}{l}0.72 \\
(0.28 / 1.2)\end{array}$ & $\begin{array}{l}0.30 \\
(0.070 / 0.57)\end{array}$ & $\begin{array}{l}+0.22 \\
(0.086 / 0.42)\end{array}$ & $\begin{array}{l}0.42 \\
73\end{array}$ & 1.60 \\
\hline $\mathrm{Mg}$ & & & $\begin{array}{l}1.0 \\
(0.72 / 2.8)\end{array}$ & $\begin{array}{l}1.2 \\
(0.80 / 1.9)\end{array}$ & $\begin{array}{l}0.60 \\
(0.27 / 1.1)\end{array}$ & $\begin{array}{l}0.46 \\
(0.26 / 0.60)\end{array}$ & $\begin{array}{l}0.95 \\
52\end{array}$ & 6.0 \\
\hline $\mathrm{Na}$ & & & $\begin{array}{l}6.0 \\
(4.9 / 10)\end{array}$ & $\begin{array}{l}4.0 \\
(3.2 / 4.7)\end{array}$ & $\begin{array}{l}2.1 \\
(1.7 / 6.7)\end{array}$ & $\begin{array}{l}1.8 \\
(1.4 / 2.2)\end{array}$ & $\begin{array}{l}4.0 \\
64\end{array}$ & 6.58 \\
\hline $\mathrm{Si}$ & & 0.0005 & $\begin{array}{l}1.8 \\
(0.52 / 4.5)\end{array}$ & $\begin{array}{l}4.2 \\
(1.2 / 7.0)\end{array}$ & $\begin{array}{l}4.1 \\
(2.1 / 7.4)\end{array}$ & $\begin{array}{l}4.7 \\
(1.7 / 5.9)\end{array}$ & $\begin{array}{l}3.6 \\
55\end{array}$ & 8.03 \\
\hline $\mathrm{Ba}$ & $\mu$ & 0.47 & $\begin{array}{l}8.6 \\
(5.8 / 13)\end{array}$ & $\begin{array}{l}15 \\
(11 / 24)\end{array}$ & $\begin{array}{l}8.4 \\
(6.1 / 13)\end{array}$ & $\begin{array}{l}7.5 \\
(4.7 / 10)\end{array}$ & $\begin{array}{l}9.2 \\
45\end{array}$ & 24.9 \\
\hline $\mathrm{La}$ & & 1.0 & $\begin{array}{l}4.3 \\
(1.1 / 7.7)\end{array}$ & $\begin{array}{l}4.9 \\
(1.7 / 7.3)\end{array}$ & $\begin{array}{l}3.0 \\
(1.6 / 5.1)\end{array}$ & $\begin{array}{l}2.5 \\
(1.1 / 4.2)\end{array}$ & $\begin{array}{l}3.8 \\
44\end{array}$ & 0.034 \\
\hline $\mathrm{Mn}$ & & & $\begin{array}{l}19 \\
(5 / 112)\end{array}$ & $\begin{array}{l}48 \\
(11 / 179)\end{array}$ & $\begin{array}{l}45 \\
(17 / 245)\end{array}$ & $\begin{array}{l}29 \\
(7 / 124)\end{array}$ & $\begin{array}{l}37 \\
79\end{array}$ & 15.9 \\
\hline $\mathrm{N}$ & & & $\begin{array}{l}354 \\
(206 / 767)\end{array}$ & $\begin{array}{l}572 \\
(289 / 806)\end{array}$ & $\begin{array}{l}320 \\
(214 / 586)\end{array}$ & $\begin{array}{l}326 \\
(173 / 449)\end{array}$ & $\begin{array}{l}383 \\
47\end{array}$ & n.a. \\
\hline $\mathrm{P}$ & & & $\begin{array}{l}8.0 \\
(0.0 / 50)\end{array}$ & $\begin{array}{l}15 \\
(7.3 / 43)\end{array}$ & $\begin{array}{l}8.0 \\
(0.0 / 21)\end{array}$ & $\begin{array}{l}12 \\
(0.0 / 23)\end{array}$ & $\begin{array}{l}11 \\
61\end{array}$ & n.a. \\
\hline $\mathrm{Sr}$ & & 0.01 & $\begin{array}{l}14 \\
(6.4 / 37)\end{array}$ & $\begin{array}{l}26 \\
(16 / 33)\end{array}$ & $\begin{array}{l}8.8 \\
(3.9 / 12)\end{array}$ & $\begin{array}{l}7.5 \\
(5.2 / 9.7)\end{array}$ & $\begin{array}{l}12 \\
95\end{array}$ & 110 \\
\hline $\mathrm{Ti}$ & & 0.1 & $\begin{array}{l}+1.5 \\
(0.3 / 17)\end{array}$ & $\begin{array}{l}2.3 \\
(0.5 / 5.8)\end{array}$ & $\begin{array}{l}2.2 \\
(0.7 / 6.8)\end{array}$ & $\begin{array}{l}2.8 \\
(0.3 / 7.3)\end{array}$ & $\begin{array}{l}2.1 \\
96\end{array}$ & 0.9 \\
\hline $\mathrm{Zn}$ & & 0.0005 & $\begin{array}{l}2.7 \\
(1.3 / 9.0)\end{array}$ & $\begin{array}{l}1.7 \\
(0.84 / 3.2)\end{array}$ & $\begin{array}{l}3.9 \\
(1.2 / 6.3)\end{array}$ & $\begin{array}{l}3.6 \\
(2.0 / 11)\end{array}$ & $\begin{array}{l}6.8 \\
90\end{array}$ & 2.68 \\
\hline As & $n$ & 15 & $\begin{array}{l}234 \\
(155 / 390)\end{array}$ & $\begin{array}{l}306 \\
(136 / 547)\end{array}$ & $\begin{array}{l}328 \\
(152 / 660)\end{array}$ & $\begin{array}{l}335 \\
(163 / 785)\end{array}$ & $\begin{array}{l}270 \\
40\end{array}$ & 630 \\
\hline $\mathrm{Be}$ & & 2 & $\begin{array}{l}23 \\
(9.0 / 60)\end{array}$ & $\begin{array}{l}41 \\
(19 / 83)\end{array}$ & $\begin{array}{l}106 \\
(46 / 208)\end{array}$ & $\begin{array}{l}58 \\
(25 / 116)\end{array}$ & $\begin{array}{l}44 \\
74\end{array}$ & 9 \\
\hline $\mathrm{Bi}$ & & 0.2 & $\begin{array}{l}2.0 \\
(0.7 / 8.6)\end{array}$ & $\begin{array}{l}5.1 \\
(1.1 / 11)\end{array}$ & $\begin{array}{l}8.4 \\
(3.4 / 36)\end{array}$ & $\begin{array}{l}12 \\
(2.4 / 44)\end{array}$ & $\begin{array}{l}4.8 \\
106\end{array}$ & 2 \\
\hline $\mathrm{Cd}$ & & 0.3 & $\begin{array}{l}14 \\
(6.5 / 53)\end{array}$ & $\begin{array}{l}10 \\
(2.7 / 23)\end{array}$ & $\begin{array}{l}18 \\
(4.3 / 41)\end{array}$ & $\begin{array}{l}18 \\
(7.2 / 48)\end{array}$ & $\begin{array}{l}13 \\
80\end{array}$ & 10 \\
\hline Co & & 0.1 & $\begin{array}{l}306 \\
(69 / 1762)\end{array}$ & $\begin{array}{l}375 \\
(51 / 1503)\end{array}$ & $\begin{array}{l}461 \\
(56 / 2265)\end{array}$ & $\begin{array}{l}211 \\
(23 / 798)\end{array}$ & $\begin{array}{l}331 ; \\
96\end{array}$ & 160 \\
\hline
\end{tabular}


Table 2. Continued.

\begin{tabular}{|c|c|c|c|c|c|c|c|c|}
\hline $\mathrm{C}$ & $\mathrm{U}$ & LOD & R. A. & R. L. & R. D. & R. G. & All & Europe median* \\
\hline $\mathrm{Cr}$ & $n$ & 7 & $\begin{array}{l}239 \\
(107 / 598)\end{array}$ & $\begin{array}{l}538 \\
(143 / 1106)\end{array}$ & $\begin{array}{l}299 \\
(97 / 999)\end{array}$ & $\begin{array}{l}328 \\
(102 / 1016)\end{array}$ & $\begin{array}{l}306 ; \\
85\end{array}$ & 380 \\
\hline $\mathrm{Cu}$ & & 3 & $\begin{array}{l}564 \\
(273 / 1566)\end{array}$ & $\begin{array}{l}713 \\
(410 / 1262)\end{array}$ & $\begin{array}{l}346 \\
(203 / 2183)\end{array}$ & $\begin{array}{l}409 \\
(188 / 708)\end{array}$ & $\begin{array}{l}541 ; \\
55\end{array}$ & 880 \\
\hline $\mathrm{Ga}$ & & 0.2 & $\begin{array}{l}19 \\
(4 / 131)\end{array}$ & $\begin{array}{l}26 \\
(5 / 72)\end{array}$ & $\begin{array}{l}37 \\
(10 / 130)\end{array}$ & $\begin{array}{l}48 \\
(7 / 135)\end{array}$ & $\begin{array}{l}26 \\
103\end{array}$ & 11 \\
\hline $\mathrm{Ge}$ & & 1 & $\begin{array}{l}10 \\
(5 / 21)\end{array}$ & $\begin{array}{l}11 \\
(5 / 17)\end{array}$ & $\begin{array}{l}19 \\
(8 / 34)\end{array}$ & $\begin{array}{l}17 \\
(7 / 23)\end{array}$ & $\begin{array}{l}12 \\
49\end{array}$ & 9 \\
\hline $\mathrm{Li}$ & & 3 & $\begin{array}{l}+784 \\
(447 / 2562)\end{array}$ & $\begin{array}{l}616 \\
(372 / 1049)\end{array}$ & $\begin{array}{l}520 \\
(338 / 972)\end{array}$ & $\begin{array}{l}372 \\
(263 / 722)\end{array}$ & $\begin{array}{l}626 \\
35\end{array}$ & 2100 \\
\hline Mo & & 0.4 & $\begin{array}{l}+34 \\
(\mathbf{1 1} / 138)\end{array}$ & $\begin{array}{l}31 \\
(14 / 69)\end{array}$ & $\begin{array}{l}48 \\
(16 / 140)\end{array}$ & $\begin{array}{l}58 \\
(31 / 112)\end{array}$ & $\begin{array}{l}38 \\
58\end{array}$ & 220 \\
\hline $\mathrm{Ni}$ & & 0.3 & $\begin{array}{l}673 \\
(318 / 1644)\end{array}$ & $\begin{array}{l}681 \\
(205 / 1053)\end{array}$ & $\begin{array}{l}334 \\
(128 / 707)\end{array}$ & $\begin{array}{l}310 \\
(111 / 613)\end{array}$ & $\begin{array}{l}516 ; \\
58\end{array}$ & 1910 \\
\hline $\mathrm{Pb}$ & & 0.2 & $\begin{array}{l}240 \\
(81 / 1729)\end{array}$ & $\begin{array}{l}407 \\
(74 / 1182)\end{array}$ & $\begin{array}{l}547 \\
(169 / 2108)\end{array}$ & $\begin{array}{l}869 \\
(133 / 3513)\end{array}$ & $\begin{array}{l}380 \\
91\end{array}$ & 93 \\
\hline $\mathrm{Sb}$ & & 0.1 & $\begin{array}{l}53 \\
(32 / 79)\end{array}$ & $\begin{array}{l}51 \\
(30 / 63)\end{array}$ & $\begin{array}{l}56 \\
(29 / 85)\end{array}$ & $\begin{array}{l}46 \\
(32 / 94)\end{array}$ & $\begin{array}{l}52 \\
21\end{array}$ & 70 \\
\hline $\mathrm{Sn}$ & & 0.4 & $\begin{array}{l}6.3 \\
(2.0 / 31)\end{array}$ & $\begin{array}{l}12 \\
(1.8 / 35)\end{array}$ & $\begin{array}{l}18 \\
(5.5 / 127)\end{array}$ & $\begin{array}{l}22 \\
(7.4 / 65)\end{array}$ & $\begin{array}{l}11 ; \\
94\end{array}$ & n.a. \\
\hline $\mathrm{Tl}$ & & 0.2 & $\begin{array}{l}9.0 \\
(5.0 / 22)\end{array}$ & $\begin{array}{l}10 \\
(3 / 20)\end{array}$ & $\begin{array}{l}11 \\
(5.0 / 20)\end{array}$ & $\begin{array}{l}14 \\
(5.3 / 21)\end{array}$ & $\begin{array}{l}11 ; \\
49\end{array}$ & 5 \\
\hline $\mathrm{U}$ & & 0.1 & $\begin{array}{l}47 \\
(14 / 144)\end{array}$ & $\begin{array}{l}81 \\
(24 / 220)\end{array}$ & $\begin{array}{l}154 \\
(56 / 798)\end{array}$ & $\begin{array}{l}388 \\
(183 / 1066)\end{array}$ & $\begin{array}{l}89 \\
116\end{array}$ & 320 \\
\hline $\mathrm{V}$ & & 0.5 & $\begin{array}{l}359 \\
(112 / 1489)\end{array}$ & $\begin{array}{l}552 \\
(95 / 1575)\end{array}$ & $\begin{array}{l}889 \\
(219 / 2753)\end{array}$ & $\begin{array}{l}1367 \\
(121 / 2792)\end{array}$ & $\begin{array}{l}541 ; \\
108\end{array}$ & 460 \\
\hline
\end{tabular}

* Median water data from Salminen et al. (2005), and n.a. indicates elements not analysed.

Statistical power analysis was performed using SPSS for Windows (v19.0). The post hoc analysis of the difference in means between headwaters and downstream using two-tailed Student's $t$ test. H0 was that there is no difference between headwater and downstream sites. H1 was that there is one. The statistical power $(1-\beta)$ gives the probability that the hypothesis is correctly rejected, a value above 0.80 indicates that $\mathrm{H} 0$ was correctly rejected.

Median and robust coefficient of variation (CV) of the difference in stream water chemistry between 40 stream reaches (all four rivers put together), 53 stream junctions with 107 tributaries vs. downstream comparisons, and 36 lakes with 77 inlets vs. outlet comparisons (Table 1). To test if the difference was significant, both Wilcoxon and paired Student's $t$ test were used.

\section{Results}

In Sweden groundwater tables are usually low in September and October. During 2007 the groundwater tables were lower than usual for this time of the year for the four rivers (SGU, 2012). The weather in September 2007 was normal (compared to $30 \mathrm{yr}$ averages), while it was $1^{\circ} \mathrm{C}$ colder and precipitation was $50 \%$ lower than usual in October (SMHI,
2012). During the sampling the HYPE modelled runoff was low and stable in R. A. and in R. G., while for R. L. and R. D. the sampling took place during the descending limb of a minor runoff episode (Fig. 2).

\subsection{Variability of chemical variables}

The Piper diagram shows that the majority of the samples were dominated by the cations $\mathrm{Na}$ and $\mathrm{K}$ and by the anions $\mathrm{Cl}$, and to a lesser degree $\mathrm{SO}_{4}$ (Fig. 3). R. A. and R. L., which are located closer to the sea and which are more heavily impacted by acid rain, had on average twice as high average concentrations of the marine derived ions $\mathrm{Cl}, \mathrm{Mg}, \mathrm{Na}$ and $\mathrm{SO}_{4}$. This was also the case for the elements $\mathrm{Cu}, \mathrm{K}, \mathrm{Li}, \mathrm{Ni}$ and Sr. R. D. and R. G. had higher concentrations of Be, Bi, $\mathrm{U}$ and $\mathrm{V}$. The following elements were under the LOD: Ag and $\mathrm{Au}<0.1$, In $<0.5$ and $\mathrm{Se}<500$ (all in $\mathrm{ng} \mathrm{L}^{-1}$ ).

The rivers are discussed in the following order: R. A., R. L., R. D., and R. G. This is in accordance with the natural gradient from the Swedish south-west coast (R. A.) up northeast to R. G. (Fig. 1). The median value decreased monotonically for $\mathrm{Cl}, \mathrm{Li}, \mathrm{Na}$ and $\mathrm{pH}$ (Table 2), from R. A. to R. G., while the opposite trend was observed for $\mathrm{As}, \mathrm{Bi}, \mathrm{Ga}, \mathrm{Pb}$, $\mathrm{Sn}, \mathrm{Tl}, \mathrm{U}$ and $\mathrm{V}$. The elements with the highest robust $\mathrm{CV}$ s (> 100), using all 243 sites, were in decreasing order $\mathrm{U}, \mathrm{Cl}$, 


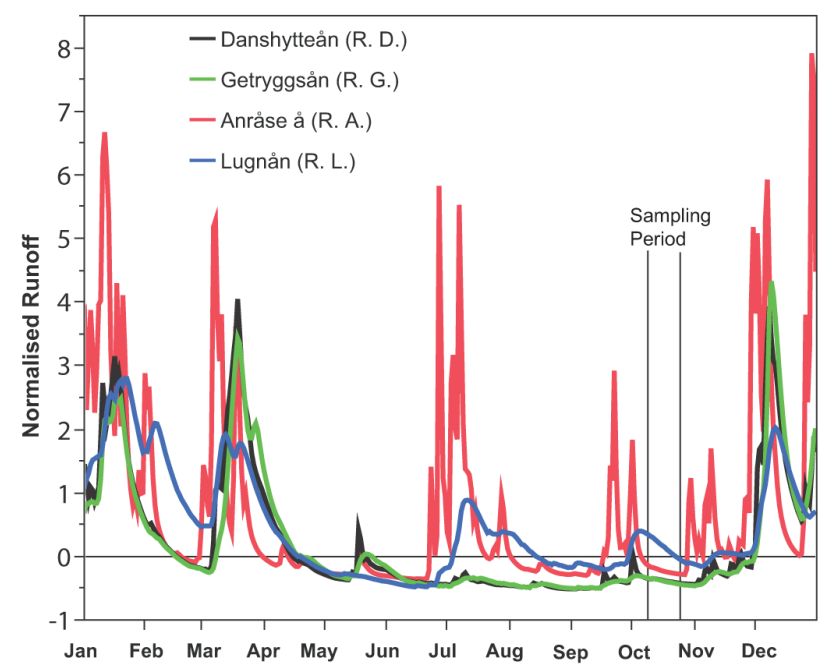

Fig. 2. Normalised daily HYPE modelled runoff ( $Q$; see Methods section for details) for 2007, where River Anråse å is represented by the red line, River Lugnån by the blue line, River Danshytteån by the black line and River Getryggsån by the green line. The vertical solid lines indicate the sampling period for all rivers in October 2007. The sampling took a maximum of three days per river; see Table 1 for exact dates and to get modelled runoff in $\mathrm{m}^{3} \mathrm{~s}^{-1}$.

$\mathrm{V}, \mathrm{Fe}, \mathrm{Bi}$, and $\mathrm{Ga}$ (the column denoted "All" in Table 2). At the other end of the scale, the chemical variables with the lowest robust $\mathrm{CVs}(<41)$ were in increasing order $\mathrm{pH}, \mathrm{Sb}$, $\mathrm{Li}$, As and $\mathrm{SO}_{4}$ (Table 2). Robust $\mathrm{CVs}$ for $\mathrm{Al}$ and TOC were 65 and 69 , respectively, meaning they are essentially "median" robust CVs of all chemical variables. Five chemical variables were chosen to exemplify trace element variation with catchment size and $\mathrm{pH}: \mathrm{Li}, \mathrm{V}, \mathrm{Ga}, \mathrm{Sb}$ and La. Higher variability with lower catchment size was generally seen for those chemical variables (Fig. 4). Higher $\mathrm{pH}$ was associated with lower $\mathrm{V}$ and $\mathrm{Sb}$ concentrations (Fig. $4 \mathrm{~d}$ and h), while $\mathrm{La}$ and $\mathrm{Li}$ concentrations increased with $\mathrm{pH}$ (Fig. $4 \mathrm{~b}$ and j). Both $\mathrm{Pb}$ and $\mathrm{Zn}$ follow the pattern of Sb and V (results not shown), while no clear $\mathrm{pH}$ dependence was observed for $\mathrm{Co}$, $\mathrm{Cu}$ or $\mathrm{Ni}$.

\subsection{Clusters of chemical variables}

All common factor analyses (FA) pass Bartlett's test of sphericity and KMO values were usually over 0.7 , except for R. G. which was 0.6. These tests indicate that all shown FA analyses shown were valid to perform, although the values were borderline for R. G.

In the factor analysis three groupings were identified (Fig. 5a):

- Near the far end of the first factor, opposite to $\mathrm{pH}$, was a cluster of $\mathrm{Al}, \mathrm{As}, \mathrm{Bi}, \mathrm{Cr}, \mathrm{Fe}, \mathrm{Ga}, \mathrm{Ge}, \mathrm{Pb}, \mathrm{Si}, \mathrm{Tl}$, TOC and $\mathrm{V}$, mainly substances associated with low $\mathrm{pH}$ conditions. This cluster is hereafter termed $\mathrm{FA} 1_{\mathrm{Chem}} 1+$.

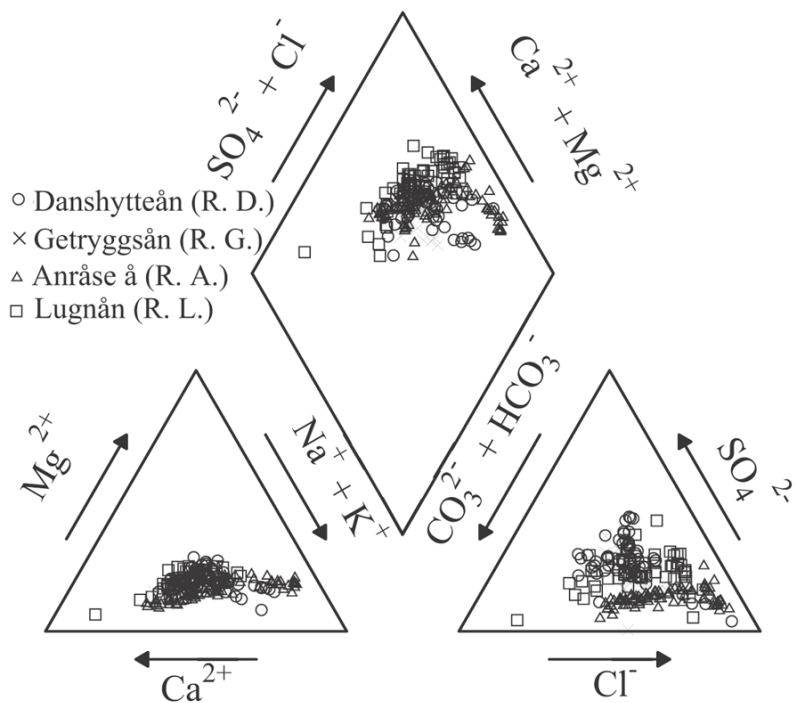

Fig. 3. Piper diagram, where River Anråse å is represented by triangles, River Lugnån by open squares, River Danshytteån by open circles and River Getryggsån by crosses.

- Another cluster, FA1 $1_{\mathrm{Chem}} 2+$, includes $\mathrm{Be}, \mathrm{Cd}, \mathrm{Sb}, \mathrm{U}$ and $\mathrm{Zn}$, close to $\mathrm{FA} 1_{\mathrm{Chem}} 1+$ but with slightly smaller eigenvalues.

- A third cluster, FA2 ${ }_{\mathrm{Chem}} 1+$, includes $\mathrm{ANC}, \mathrm{Ca}, \mathrm{K}, \mathrm{La}$, $\mathrm{Mg}, \mathrm{Na}, \mathrm{SO}_{4}$ and $\mathrm{Sr}$, located at the positive end of the second factor.

Along the first factor lake surface coverage was the map information with the highest negative eigenvalue (Fig. 5a), opposite of $\mathrm{FA} 1_{\mathrm{Chem}} 1+$. Positive values along the first axis were forest and altitude (Fig. 5a). Cluster FA2 ${ }_{\mathrm{Chem}} 1+$ covaries positively with open fields (such as arable, pasture and open fields), while forest coverage and altitude were opposite to FA2 ${ }_{\text {Chem }} 1+$ (Fig. 5a). The patterns observed in Fig. 5a could, to some degree, be observed in Fig. 5c-f, although the pattern for R. A. (Fig. 5e) was roughly a mirror image of the FA analysis for the other three rivers. Perhaps the most notable FA result was that $\mathrm{Cu}$ did not co-vary with TOC and Zn (Fig. 5a, c-f). Based on the score plot, some sites in R. A. and R. D. showed differences between the four rivers, but most sites overlapped based on scores, indicating that they have a rather similar spatial pattern (Fig. 5b). The Piper plot confirms the rather good similarity between the rivers, except one site at R. L. that behaved differently (Fig. 3).

\subsection{Headwaters compared to downstream}

The variability was generally higher in the headwaters $\left(<2 \mathrm{~km}^{2}\right)$ compared to sites further downstream. The median concentration values decreased with increasing catchment size, with some exceptions. The catchment with the fewest significant chemical differences between headwaters 
and downstream sites was R. L. The biggest differences were observed for R. G., with both increasing (ANC, $\mathrm{Ca}, \mathrm{K}, \mathrm{pH}$ and $\mathrm{SO}_{4}$ ) and decreasing ( $\mathrm{Al}, \mathrm{As}, \mathrm{Ba}, \mathrm{Be}, \mathrm{Cd}, \mathrm{Co}, \mathrm{Cr}, \mathrm{Fe}$, $\mathrm{Ga}, \mathrm{Ge}, \mathrm{Li}, \mathrm{N}, \mathrm{Ni}, \mathrm{P}, \mathrm{Pb}, \mathrm{Si}, \mathrm{Sn}, \mathrm{Ti}, \mathrm{Tl}, \mathrm{TOC}, \mathrm{V}$ and $\mathrm{Zn}$ ) concentrations with increasing catchment size (Table 2). All significant changes in R. D. showed lower downstream concentrations ( $\mathrm{Al}, \mathrm{Ba}, \mathrm{Be}, \mathrm{Cd}, \mathrm{Co}, \mathrm{Cr}, \mathrm{Ga}, \mathrm{Ge}, \mathrm{Si}$, Ti and $\mathrm{Tl}$ ). In R. A., both significant increases ( $\mathrm{Li}, \mathrm{Mo}, \mathrm{pH}$ and $\mathrm{Ti}$ ) and decreases $(\mathrm{Cd}, \mathrm{Co}$ and $\mathrm{Zn}$ ) were detected (Table 2).

\subsection{Comparison of stream reaches, stream junctions and lakes}

When comparing concentrations within the same stream channel $(n=40)$ the following showed significant differences: $\mathrm{Cl}, \mathrm{K}, \mathrm{Mg}, \mathrm{Mo}, \mathrm{Na}, \mathrm{Ni}, \mathrm{Sb}, \mathrm{Sr}$, Ti and V (Table 3), which all increased in concentration except $\mathrm{Sb}$, which decreased. The 53 stream junctions had in total 107 tributaries and the following elements changed significantly when comparing inlets with the site downstream the junction: $\mathrm{Cd}, \mathrm{Co}$, $\mathrm{Ge}, \mathrm{pH}$ and $\mathrm{Tl}$ increased while the others decreased in concentration (Table 3). For 36 lakes, comparisons of 77 pairs of inlet vs. outlet concentrations gave significant differences for: $\mathrm{Al}, \mathrm{As}, \mathrm{Ba}, \mathrm{Bi}, \mathrm{Ca}, \mathrm{Cd}, \mathrm{Cl}, \mathrm{Co}, \mathrm{Cr}, \mathrm{Fe}, \mathrm{Ga}, \mathrm{Ge}, \mathrm{K}, \mathrm{N}, \mathrm{Na}$, $\mathrm{Ni}, \mathrm{P}, \mathrm{Pb}, \mathrm{pH}, \mathrm{Si}, \mathrm{Sn}, \mathrm{SO}_{4}, \mathrm{Ti}, \mathrm{Tl}, \mathrm{TOC}, \mathrm{U}, \mathrm{V}$ and $\mathrm{Zn}$ (Table 3); all with decreasing concentrations except for $\mathrm{Ca}, \mathrm{K}$, $\mathrm{pH}$ and $\mathrm{SO}_{4}$, which showed an increase.

\subsection{Comparison with long-term time series and analysis of sampling technique}

We used data, covering the period October 1996-2009, from 132 reference sites at the Swedish national environmental monitoring programme for watercourses in southern Sweden for comparison with observed concentrations in the present study (same sites as in Huser et al., 2011). Concentrations of $\mathrm{Co}, \mathrm{Fe}$ and TOC from this study were usually higher than the median of the national programme, while this study's values were lower for $\mathrm{Cu}$, Mo and $\mathrm{Zn}$. In general, the observed concentrations of $\mathrm{Al}, \mathrm{Fe}, \mathrm{Pb}$ and TOC were higher in our study compared to the median of water samples in the Geochemical Atlas of Europe (the column denoted "Europe median" in Table 2) (Salminen et al., 2005). While $\mathrm{Ca}, \mathrm{K}, \mathrm{Mo}, \mathrm{pH}$ and $\mathrm{SO}_{4}$ were lower in our study compared to the median in the Geochemical Atlas of Europe.

This study was based on unfiltered samples because the filtering process in these humic and iron rich systems may create artefacts (Sholkovitz, 1992; Köhler, 2010). There were few sites that had enough inorganic particles in our study to change that. However, in the lower parts of R. A. there were silty soils and livestock, potentially influencing the amount of inorganic particles suspended in the samples. Acidifying (using $\mathrm{HNO}_{3}$ ) the unfiltered samples at $\mathrm{R}$. A. could be the reason why some rather similar trace elements had the highest or the lowest robust CV. Thus, the lack of filtering could

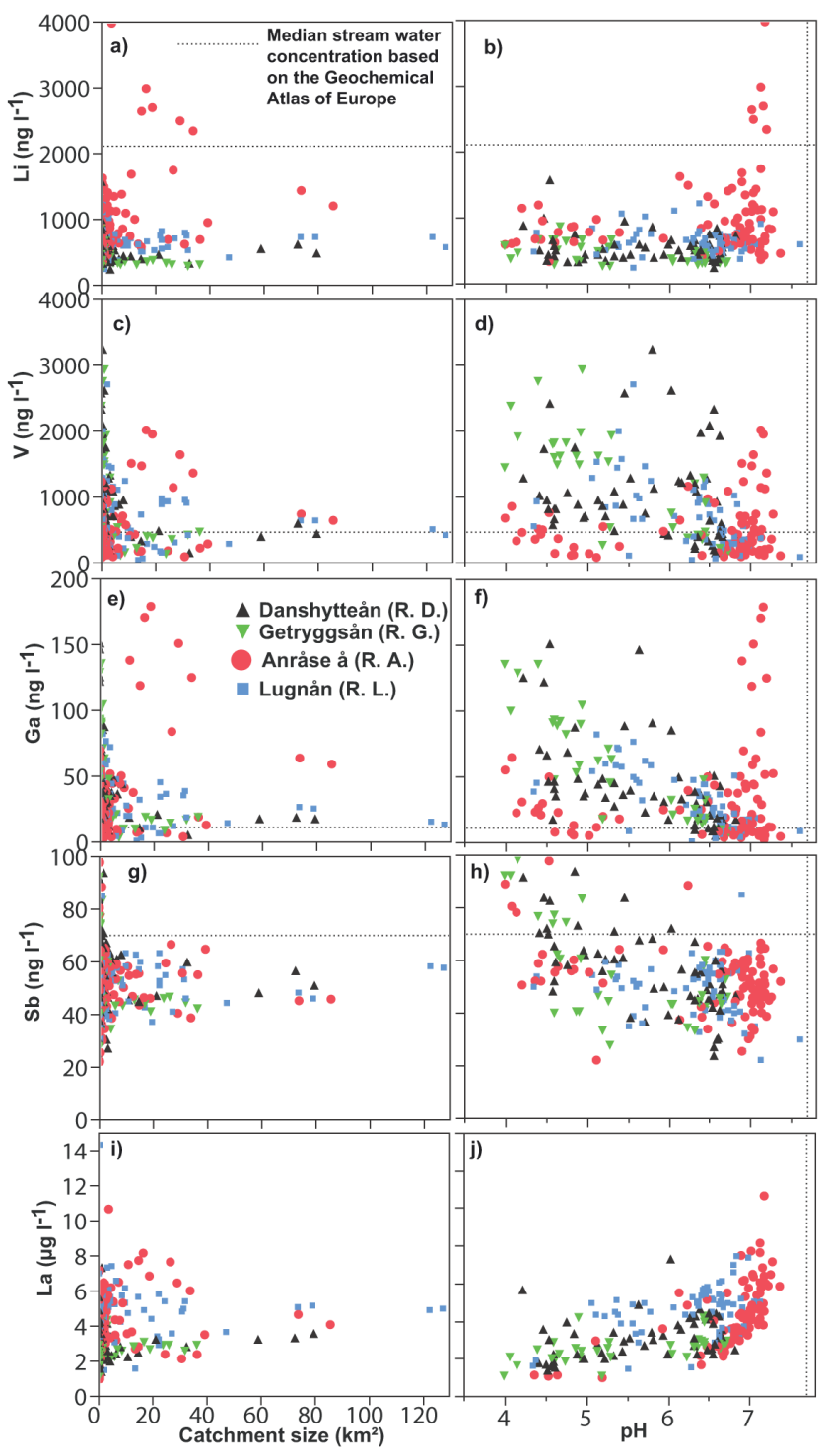

Fig. 4. Chemistry variation with catchment size (left panel) and $\mathrm{pH}$ (right panel) for several trace elements; (a-b) Li, (c-d) V, (e-f) Ga, (g-h) Sb and (i-j) La. River Anråse å is represented by red dots, River Lugnån by blue squares, River Danshytteån by black triangles (pointed up) and River Getryggsån by green triangles (pointed down). Dashed lines are median stream water concentrations and $\mathrm{pH}$ according to the Geochemical Atlas of Europe (Salminen et al., 2005). For La the European value, $0.034 \mu \mathrm{g} \mathrm{L}^{-1}$, is too low to be seen on the graph.

be the cause of the apparent increases in Li and Mo in downstream sites. This was the only river where we found significant differences between filtered (at $0.45 \mu \mathrm{m}$ ) and unfiltered absorbance at $420 \mathrm{~nm}$ (absDIFF) (Fig. 6). At all other rivers absDIFF was smaller than $7 \%$ on average. 


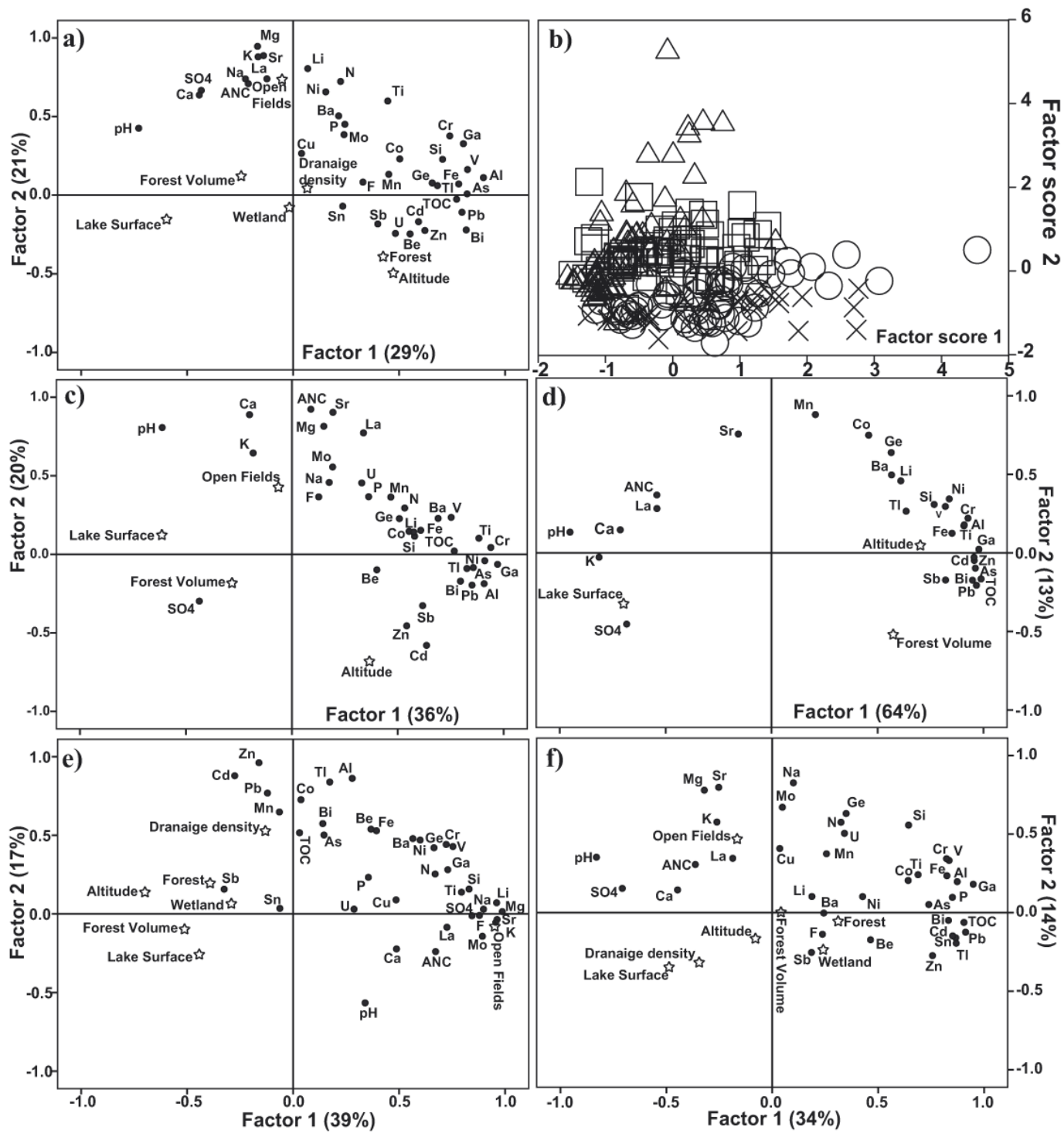

Fig. 5. Common factor analysis of water chemistry and map material (Table 1): (a-b) data from all four rivers, where (a) is the loading plot, (b) is the score plot. Loading plots for (c) Danshytteån (R. D.), (d) Getryggsån (R. G.), (e) Anråse å (R. A.) and (f) Lugnån (R. L.). In (b) R. A. is represented by triangles, R. L. by open squares, R. D. by open circles and R. G. by crosses. For (a) and (c-f) black dots are water chemistry and open stars are physical parameters (map information).

\section{Discussion}

Trace elements may originate from anthropogenic point or diffuse sources or from the bedrock and soil. They are mobilised under favourable geochemical conditions (typically acidic $\mathrm{pH}$ ) in the presence of colloidal carrier phases such as organic carbon or sesquioxide particles (Al, Fe and Mn oxyhydroxides) and in the form of other inorganic complexes such as chlorides, fluorides, hydroxides, carbonates or sulphates. Organic carbon is a major controlling factor on both trace elements mobility and $\mathrm{pH}$ in most of the running waters and lakes in this study. The main hypothesis in this study was that trace elements follow the same spatial pattern as TOC, and that concentration decreases from upstream to downstream sites, mainly due to the position and volume of lakes. We can not reject the hypothesis for $\mathrm{As}, \mathrm{Ba}, \mathrm{Be}, \mathrm{Bi}, \mathrm{Cd}, \mathrm{Co}$, $\mathrm{Cr}, \mathrm{Ga}, \mathrm{Ge}, \mathrm{Ni}, \mathrm{Pb}, \mathrm{Sn}, \mathrm{Ti}, \mathrm{Tl}, \mathrm{U}, \mathrm{V}$ and Zn (Fig. 5a), as they follow a similar spatial pattern as TOC (as well as $\mathrm{Al}$ and $\mathrm{Fe}$ ) when comparing lake inlets and outlets (Table 3). The largest absolute changes in sites downstream of lakes were observed for sites in R. D. and R. G. that have a lower lake surface coverage and also lower specific average runoff. The trace elements that did not show a significant decrease in concentration when comparing inlets with outlets at lakes were $\mathrm{Cu}$, $\mathrm{La}, \mathrm{Li}, \mathrm{Mo}, \mathrm{Sb}$ and $\mathrm{Sr}$ (but also $\mathrm{Mg}$ and $\mathrm{Mn}$ ) (Table 3), most of which are discussed below. Significant increases in lakes 
Table 3. Median and robust coefficient of variation $(\mathrm{CV})$ of the difference between (1) stream reaches $(n=40)$, (2) stream junctions (53 junctions with 107 tributaries vs. downstream comparisons) and (3) lakes (36 lakes with 77 inlets vs. outlets comparisons). Significant differences using both Wilcoxon and paired Student's $t$ test are marked with * for $p<0.05$ and $* *$ for $p<0.01$. For units, see Table 2.

\begin{tabular}{|c|c|c|c|}
\hline $\mathrm{C}$ & (1) Reaches & (2) Junctions & (3) Lakes \\
\hline $\mathrm{Al}$ & $5.1(10)$ & $-0.08(-1116)$ & $-127 * *(-1.6)$ \\
\hline ANC & $5.9(5.0)$ & $3.5(12)$ & $32(2.9)$ \\
\hline As & $-1.9(-23)$ & $-6.4(-9.6)$ & $-17 *(-7.6)$ \\
\hline $\mathrm{Ba}$ & $0.23(4.4)$ & $-0.08(-12)$ & $-0.60 *(-4.0)$ \\
\hline $\mathrm{Be}$ & $3.2(2.9)$ & $-0.06(-162)$ & $-8.1 * *(-2.6)$ \\
\hline $\mathrm{Bi}$ & $0.35(3.3)$ & $-0.14(-15)$ & $-1.3 * *(-3.3)$ \\
\hline $\mathrm{Ca}$ & $48(6.3)$ & $39(14)$ & $802 * *(2.0)$ \\
\hline $\mathrm{Cd}$ & $-0.10(-27)$ & $-0.90 *(-5.8)$ & $-4.9 * *(-1.9)$ \\
\hline $\mathrm{Cl}$ & $0.13^{* *}(2.4)$ & $0.07(11)$ & $-0.33 * *(-2.0)$ \\
\hline $\mathrm{Co}$ & $41(2.9)$ & $-12 *(-16)$ & $-174 * *(-2.0)$ \\
\hline $\mathrm{Cr}$ & $32(2.6)$ & $-8.2(-12)$ & $-72 * *(-3.0)$ \\
\hline $\mathrm{Cu}$ & $45(3.5)$ & $50(2.8)$ & $-1.8(-114)$ \\
\hline $\mathrm{F}$ & $0.0010(7.0)$ & $0.0010(15)$ & $0.00(27)$ \\
\hline $\mathrm{Fe}$ & $70(2.6)$ & $0.49(524)$ & $-138 * *(-3.8)$ \\
\hline $\mathrm{Ga}$ & $2.4(4.1)$ & $-0.67(-18)$ & $-9.8 * *(-2.7)$ \\
\hline $\mathrm{Ge}$ & $0.95(3.2)$ & $-0.69 *(-4.8)$ & $-0.76 *(-6.2)$ \\
\hline $\mathrm{K}$ & $34 * *(2.2)$ & $7.8(16)$ & $55^{*}(2.9)$ \\
\hline $\mathrm{La}$ & $0.22(1.9)$ & $-0.08(-9.3)$ & $0.12(10)$ \\
\hline $\mathrm{Li}$ & $50(2.8)$ & $-6.8(-28)$ & $-29(-6.8)$ \\
\hline $\mathrm{Mg}$ & $62 * *(1.4)$ & $2.5(54)$ & $-0.42(-409)$ \\
\hline $\mathrm{Mn}$ & $0.98(14)$ & $-0.08(-197)$ & $-3.8(-6.9)$ \\
\hline Mo & $4.0^{* *}(2.6)$ & $0.29(50)$ & $-2.4(-7.6)$ \\
\hline $\mathrm{N}$ & $9.0(7.7)$ & $-3.0(-27)$ & $-37 *(-3.8)$ \\
\hline $\mathrm{Na}$ & $123 *(2.2)$ & $24(17)$ & $-182 *(-2.3)$ \\
\hline $\mathrm{Ni}$ & $41 *(2.3)$ & $-13(-8.9)$ & $-90 * *(-2.1)$ \\
\hline $\mathrm{P}$ & $0\left(4.3^{I Q R}\right)$ & $-1.0(-5.2)$ & $-1.0 *(-6.7)$ \\
\hline $\mathrm{Pb}$ & $40(3.3)$ & $-3.5(-42)$ & $-149 * *(-3.0)$ \\
\hline $\mathrm{pH}$ & $0.03(5.7)$ & $0.04 *(5.1)$ & $0.31 * *(3.1)$ \\
\hline $\mathrm{Sb}$ & $-2.1 *(-2.3)$ & $0.32(24)$ & $3.1(2.9)$ \\
\hline $\mathrm{Si}$ & $223(2.9)$ & $24(34)$ & $-1103 * *(-1.6)$ \\
\hline $\mathrm{Sn}$ & $0.07(48)$ & $-0.49(-9.6)$ & $-2.1 * *(-5.3)$ \\
\hline $\mathrm{SO}_{4}$ & $0.02(12)$ & $0.04(14)$ & $0.40 * *(2.2)$ \\
\hline $\mathrm{Sr}$ & $0.50 * *(2.0)$ & $-0.03(-49)$ & $0.01(243)$ \\
\hline $\mathrm{Ti}$ & $0.26 *(3.4)$ & $0.07(14)$ & $-0.68 * *(-2.3)$ \\
\hline $\mathrm{Tl}$ & $0.80(3.3)$ & $-0.38 *(-5.8)$ & $-2.8^{* *}(-1.8)$ \\
\hline TOC & $0.03(27)$ & $-0.14(-17)$ & $-2.0 * *(-4.8)$ \\
\hline $\mathrm{U}$ & $15(2.6)$ & $-4.0(-9.4)$ & $-11 *(-4.1)$ \\
\hline V & $53 *(3.8)$ & $-26(-9.0)$ & $-182 * *(-2.7)$ \\
\hline $\mathrm{Zn}$ & 87 (4.9) & $-163(-5.2)$ & $-691 * *(-2.0)$ \\
\hline
\end{tabular}

Index $\mathrm{IQR}=$ normalised interquartile range (since median is null).

were detected for $\mathrm{Ca}, \mathrm{K}, \mathrm{pH}$ and $\mathrm{SO}_{4}$. These results suggest that there could be a connection between the levels of $\mathrm{Cu}$, $\mathrm{La}, \mathrm{Li}, \mathrm{Mo}, \mathrm{Sb}$ and $\mathrm{Sr}$ and those of $\mathrm{Ca}, \mathrm{K}, \mathrm{pH}$ and $\mathrm{SO}_{4}$. In R. G. there was a significant decrease in TOC between headwater and downstream sites, along with $\mathrm{Al}, \mathrm{Ba}, \mathrm{Be}, \mathrm{Bi}, \mathrm{Cd}$, $\mathrm{Co}, \mathrm{Cr}, \mathrm{Fe}, \mathrm{Ga}, \mathrm{Ge}, \mathrm{Li}, \mathrm{Ni}, \mathrm{Pb}, \mathrm{Si}, \mathrm{Sn}, \mathrm{Ti}, \mathrm{Tl}, \mathrm{U}, \mathrm{V}$ and $\mathrm{Zn}$, while $\mathrm{ANC}, \mathrm{Ca}, \mathrm{K}, \mathrm{pH}$ and $\mathrm{SO}_{4}$ increased. In the other rivers
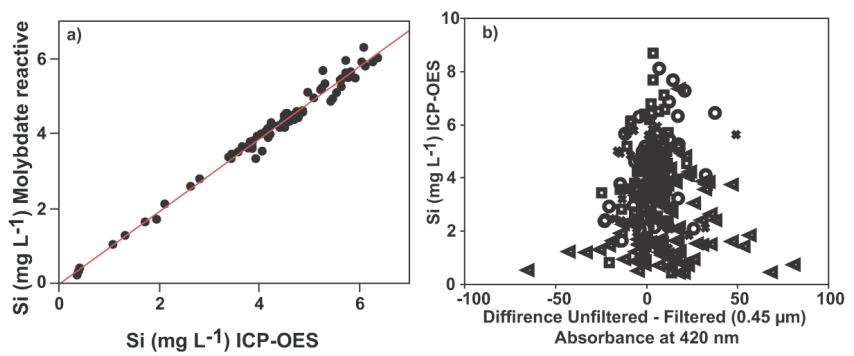

Fig. 6. (a) Concentration of molybdate reactive silica $\left(\mathrm{mg} \mathrm{L}^{-1}\right)$ against total silica measured by ICP-OES measured at the monitoring sites (Aneboda, Gårdsjön and Kindla) that were within the samples catchments, and (b) comparison of absorbance at $420 \mathrm{~nm}$, unfiltered - filtered $(0.45 \mu \mathrm{m})$, against total silica $\left(\mathrm{mg} \mathrm{L}^{-1}\right)$ ICPOES in the presented data set. R. A. is represented by triangles, R. L. by open squares, R. D. by open circles and R. G. by crosses.

there were significant downstream decreases in $\mathrm{Cd}$ and $\mathrm{Co}$. At R. D. the concentrations of $\mathrm{Al}, \mathrm{Ba}, \mathrm{Be}, \mathrm{Cr}, \mathrm{Ga}, \mathrm{Ge}, \mathrm{Si}$, $\mathrm{Ti}$ and $\mathrm{Tl}$ decreased downstream, and for R. A. there was an increase in concentration of $\mathrm{Li}, \mathrm{Mo}, \mathrm{pH}$ and $\mathrm{Ti}$ (Table 2).

Elements for which significant downstream losses were observed at all rivers include $\mathrm{Al}, \mathrm{Be}, \mathrm{Fe}, \mathrm{Ga}, \mathrm{Ge}, \mathrm{Si}$, Ti and Tl. All of these elements have in common that they bind comparatively strong to hydroxide ions (Stumm and Morgan, 1996). They may form neutral species in water when $\mathrm{pH}$ increases, such as may be observed during the passage of a lake with internal alkalinity production. Elements that mainly form cationic species, such as $\mathrm{La}$ and $\mathrm{Sr}$, or predominantly exist in the anionic form, such as As, Mo, Sb or V, are not removed during a lake passage or are removed only when iron is removed simultaneously.

For R. A., R. L. and R. D., no significant changes in TOC were detected between headwater and downstream sites. The same holds for $\mathrm{pH}$ in R. L. and R. D. It is unclear how much the differences/ similarities in the spatial patterns of chemistry between the four rivers could be due to differences/ similarities in the runoff rates during sampling (Fig. 2). Classic heavy metals such as $\mathrm{Cd}, \mathrm{Co}, \mathrm{Cu}, \mathrm{Pb}$ or $\mathrm{Zn}$ do not show any strong geographical or sea salt controlled pattern contrary to what we expected. Only $\mathrm{Pb}$ and $\mathrm{Zn}$ seem to be mobilised preferentially under acidic conditions, while $\mathrm{Co}, \mathrm{Cu}$ and $\mathrm{Ni}$ display varying concentrations irrespective of $\mathrm{pH}$. This behaviour could indicate that the latter elements were mobilised depending on geological variations of trace minerals, while $\mathrm{Pb}$ and $\mathrm{Zn}$ were present but immobilised under higher $\mathrm{pH}$.

The overall FA analysis indicates that there were roughly three clusters of elements, major elements to the upper left, $\mathrm{Fe}$ and TOC related trace elements to the right and number of elements in between those two groups. This indicates various drivers, and element behaviour also varies in between rivers. $\mathrm{Al}, \mathrm{Fe}$ and TOC have a strong negative correlation to $\mathrm{pH}$ in many Swedish surface waters, indicating TOC as a major driver for $\mathrm{pH}, \mathrm{Fe}$ and $\mathrm{Al}$ mobility (Köhler et al., 2000; 

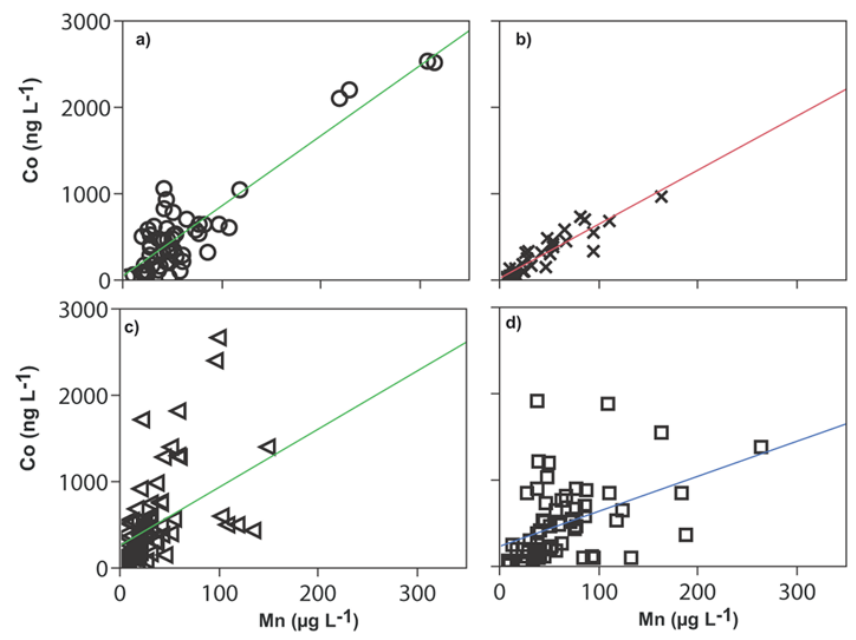

Fig. 7. Concentration of total cobalt $\left(n \mathrm{LL}^{-1}\right)$ against total manganese $\left(\mu \mathrm{g} \mathrm{L}^{-1}\right)$ at the four rivers (a) Danshytteån, (b) Getryggsån, (c) Anråse å and (d) Lugnån.

Buffam et al., 2007; Sjöstedt et al., 2010), which is why these two factors are confounded. A detailed analysis of this behaviour is outside the scope of this article and will thus not be presented here. Instead we want to focus here on some specific observations only. The trace elements described here may be divided in many different ways according to their physical and chemical properties.

\subsection{Major soluble cations ( $\mathrm{Ca}, \mathrm{K}, \mathrm{Mg}$ and $\mathrm{Na}$ )}

The major cation concentrations in the streams are controlled by deposition, weathering, biomass uptake and ionexchange. Detailed descriptions of these processes and fitted models to cation fluxes of three sites inside the catchments R. A., R. L. and R. D. may be found in Köhler et al. (2011). Higher deposition fluxes of both anthropogenically derived acids and marine derived sea salt both lead to increasing salt loads in R. A. and R. L. as compared to R. D. and R. G. sites. If the Piper plot (Fig. 3) where to be presented separately for each river, it would be easier to note that some sites, in each river, differ in their composition (as the Piper plots in Fölster et al., 2011, with the same sites but sampling in spring 2008). For R. G. no liming occurred in 2005-2007, but $27 \%$ of the sites differed anyway in their $\mathrm{Ca} / \mathrm{Mg}$ ratio. A few other sites (one in each river) seem to have a different composition due to unknown liming activity or due to Quaternary soils with a different chemical signature. In R. A. elevated Ca concentrations were due to liming activity. After excluding limed sites almost constant $\mathrm{Ca} / \mathrm{Mg}$ ratios were observed at almost all other sites, indicating somewhat homogeneous net cation mobilisation at most sites.

\subsection{Major soluble components in anionic form $(\mathrm{C}, \mathrm{Cl}, \mathrm{F}$, $\mathrm{N}, \mathrm{P}, \mathrm{S}$ and $\mathrm{Si}$ )}

At the rivers R. A. and R. L., which are close to the sea, marine derived $\mathrm{S}$ and $\mathrm{Cl}$ are much higher than at the other rivers, while this was not the case for $\mathrm{F}, \mathrm{N}$ and $\mathrm{P}$. The two latter are heavily influenced by agricultural practice and plant uptake, while the concentration variations in $\mathrm{F}$ probably reflect variations in $\mathrm{F}$ bearing minerals such as apatite or muscovite, etc. $\mathrm{Si}$ was mainly in soluble form. Comparisons of molybdate reactive $\mathrm{Si}$ and Si determined with ICP-OES at R. A. and R. L. (slope $=1.00 \pm 0.05, n=44, R^{2}=0.92$ ) do not indicate any differences (Fig. 6a). We thus assume that the possible contribution from $\mathrm{Si}$ by clay particles $(<0.2 \mathrm{ppm})$ is negligible. Initially $\mathrm{Si}$ was derived from weathering and does not show any geographical pattern. Recently the importance of Si recycling from biologically derived material was documented in boreal areas (Engström et al., 2010). Our finding of Si clustering together with TOC and $\mathrm{Fe}$ may be a hint that significant amounts of Si have been recycled and were mobilised together with TOC from organic rich riparian soils.

\subsection{Trace cations in stable oxidation states $\mathrm{Al}, \mathrm{Ba}, \mathrm{Be}$, Bi, Cd, Co, Cs, Cu, Ga, Ge, La, Li, Ni, Sn, Sr, Pb, Ti, $\mathrm{U}$ and $\mathrm{Zn}$ )}

Our overall and site specific FA analyses confirm many of the known drivers for trace element mobility, such as the effect of $\mathrm{pH}$ on trace elements concentration in general (Figs. 45), and the strong binding of $\mathrm{Co}$ to $\mathrm{MnO}_{2}, \mathrm{Cr}$ to $\mathrm{Al}$, and $\mathrm{Pb}$ to $\mathrm{Fe}(\mathrm{OH})_{3}$. Many of those latter elements relate in a very linear fashion at all sites (for $\mathrm{Co}$ vs. $\mathrm{Mn}$ and $\mathrm{Al}$ vs. $\mathrm{Cr}$, see Figs. 7-8, respectively). The liming activity (both $\mathrm{Ca}$ and $\mathrm{pH}$ ) could have an impact on the spatial patterns at other sites (Egeberg and Håkedal, 1998; Lydersen et al., 2002), but it is considered to be low in our case, since none of the trace elements were related to dose of liming in R. A. and R. L. (data not shown). However, Fe concentrations decrease with increasing lime dose at both rivers. For $\mathrm{Pb}$ and $\mathrm{Zn}$ we used the equations published by Ejhed et al. (2012) to estimate the fraction of those elements that would not pass a $0.45 \mu \mathrm{m}$ filter. The equations were based on a large data set of samples $(n=800)$ from Swedish watercourses and lakes that were sampled for both total and filtered metals. As those empirical equations were mainly driven by $\mathrm{pH}$ and water colour, we chose to plot the calculated fraction as a function of $\mathrm{pH}$ for each site (Fig. 9). The calculated fraction of metals in particulate form rises with $\mathrm{pH}$ and was generally much higher for $\mathrm{Pb}$ than for $\mathrm{Zn}$.

In R. A., the river that is most affected by marine sea salt spray, we observed strong correlations of $\mathrm{Cl}$ to a large number of trace elements. At this river a significant correlation between $\mathrm{SO}_{4}$ and $\mathrm{Cu}$ was also observed. This may indicate an effect of soil solution ionic strength from marine sea salt 


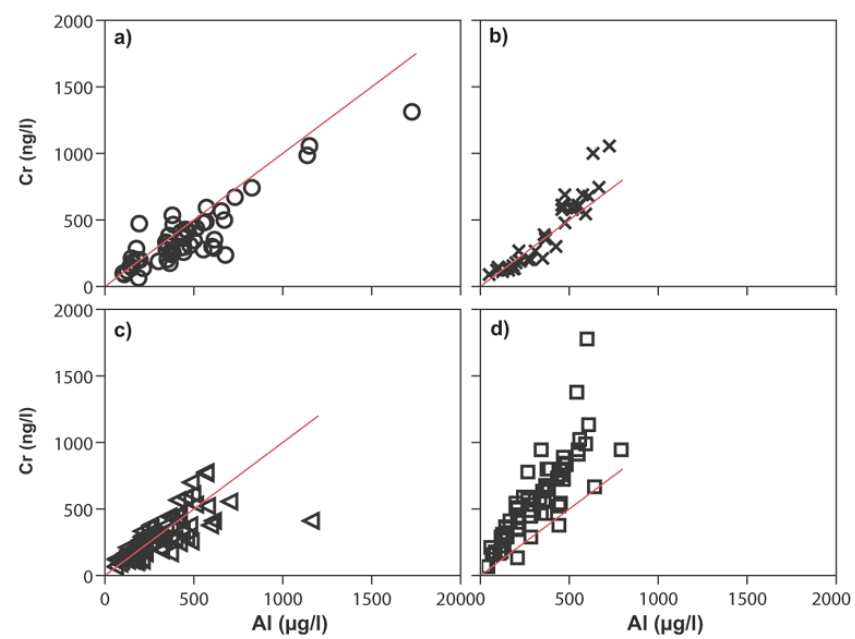

Fig. 8. Concentration of total chromium $\left(\mathrm{ng} \mathrm{L}^{-1}\right)$ against total aluminium $\left(\mu \mathrm{g} \mathrm{L}^{-1}\right)$ at the four rivers (a) Danshytteån, (b) Getryggsån, (c) Anråse å and (d) Lugnån.
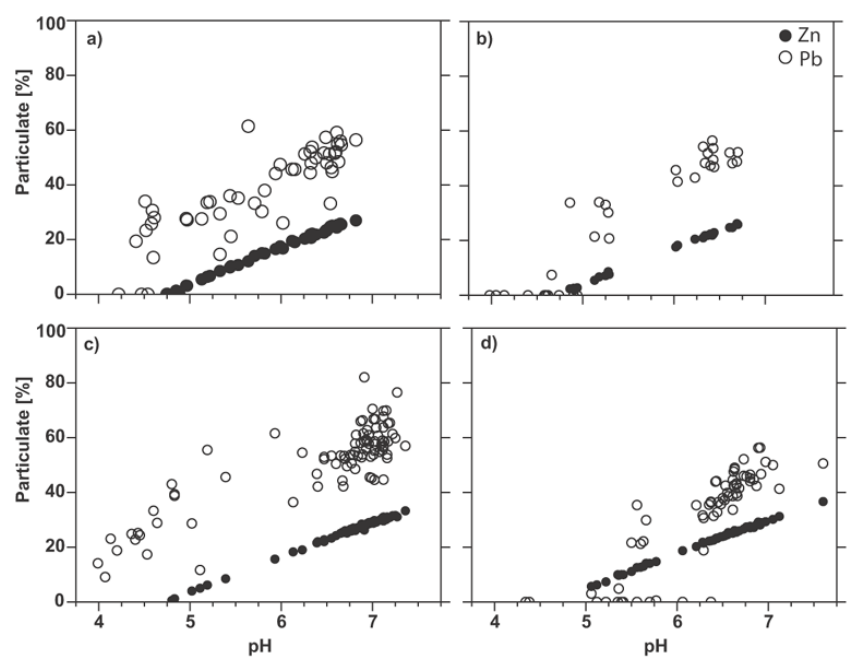

Fig. 9. Particulate fraction of $\mathrm{Pb}$ and $\mathrm{Zn}$ based on equations by Ejhed et al. (2012), estimating the fraction (\%) that would not pass a $0.45 \mu \mathrm{m}$ filter at the four rivers (a) Danshytteån, (b) Getryggsån, (c) Anråse å and (d) Lugnån. The equations were based on a large data set of samples $(n=800)$ from Swedish watercourses and lakes that were sampled for both total and filtered metals. As those empirical equations were mainly driven by $\mathrm{pH}$ and water colour, we chose to plot the calculated fraction as a function of $\mathrm{pH}$ for each site.

sources on the mobilisation of elements at that river and/or mobilisation of $\mathrm{Cu}$ due to the impact of acid rain.

According to our FA analysis (Fig. 5), Cu does not co-vary strongly with $\mathrm{Al}, \mathrm{Fe}, \mathrm{TOC}$ or $\mathrm{Zn}$, despite that organic ligands are known to strongly bind $\mathrm{Cu}$ (Bresnahan et al., 1978; Hart, 1981). $\mathrm{Cu}$ and $\mathrm{Zn}$ behaved differently during the passage from the inlet to the outlet of lakes (Table 3), possibly due to differences in sedimentation (see Table 11.5 in Stumm, 1992). Similar findings for $\mathrm{Cu}$ were observed in a Swedish national survey of 1200 lakes (see PCA plots on page 196 and 202 in SEPA, 1999). Cu behaved differently compared to $\mathrm{Zn}$ (Table 2), and had no significant correlation with TOC, when evaluating Swedish time series of trace elements in 139 streams (Huser et al., 2011). Other articles have dealt with this difference in behaviour between $\mathrm{Cu}$ and $\mathrm{Zn}$ (e.g. Ross and Sherrell, 1999; Lawlor and Tipping, 2003; Tipping et al., 2010).

The non-hydrolysed cations $\mathrm{La}$ and $\mathrm{Sr}$ were not removed during river or lake passage. Elements potentially binding strongly to colloidal phases of $\mathrm{Al}, \mathrm{Fe}, \mathrm{Mn}$ and/or organic matter such as $\mathrm{Co}, \mathrm{Cr}, \mathrm{Pb}$ and maybe even $\mathrm{Ba}$ and $\mathrm{Ga}$ are removed when alkalinity, pH or TOC changes occur. Surprisingly this is not the case for $\mathrm{Cu}$ and $\mathrm{U}$, which both are known to bind strongly to these colloidal phases. Potentially $\mathrm{La}, \mathrm{Cu}$ and $\mathrm{U}$ bind very strong to fractions of organic matter that are not easily removed during lake passage. Alternatively in the case of La, the strong relationship of La to ANC may be due to the co-variation of La with alkalinity $\left(R^{2}=0.76\right)$ at $\mathrm{R}$. A., potentially indicating La mobilisation from carbonates in solution (Johannesson et al., 2004).

\subsection{Trace cationic elements in varying (I-IV) oxidation states $(\mathrm{Cr}, \mathrm{Fe}, \mathrm{Mn}$ and $\mathrm{Tl})$}

We have no analytical data on the oxidation state of these elements despite this being a strong driver for their mobility and binding. $\mathrm{Fe}$ and $\mathrm{Mn}$ are known to partly exist as $\mathrm{Fe}(\mathrm{II})$ and $\mathrm{Mn}$ (II) in the presence of organic matter, preventing hydrolysis. We assume though that the majority of both of those elements were mostly present in their oxidized form Fe(III) and $\mathrm{Mn}(\mathrm{IV}+)$ in these well-oxygenated surface waters. The strong correlation of Co with Mn may be an indicator that $\mathrm{Mn}$ was present as $\mathrm{MnO}_{2}$ colloid, to which Co is known to bind strongly (Pokrovsky et al., 2011). In a similar way we may argue for $\mathrm{Cr}$ being in the anionic form as $\mathrm{Cr}(\mathrm{V})$ bound to aluminium or organic aluminium colloids (cf. strong correlation between $\mathrm{Al}$ and $\mathrm{Cr}$ in the Fig. 8).

\subsection{Trace anionic elements (As, Mo, Sb and V)}

The anionic elements As, Mo, Sb and V did not seem to behave in a similar manner (Fig. 5). While As and V were removed at R. G., potentially together with $\mathrm{Fe}$ in accordance with the predicted speciation calculations by Wällstedt et al. (2010), Mo did not showed any removal (Tables 2-3). Very little information was available for Mo in boreal surface waters.

\subsection{Land use}

In our analysis we did not find any of our available landscape variables adding significant additional explained variance to the FA analysis (Fig. 5). The information contained in our landscape data is probably too unspecific for exploring geochemical variations quantitatively and instead represents 
only chemical, physical and biological processes. The strong removal of a large number of trace elements when passing through lakes is evident though in the FA analysis where lake surface coverage plots opposite to many of those elements (Fig. 5). Forest volume does not respond in a similar systematic fashion, and, surprisingly, the amount of wetland does not relate strongly to either TOC or Fe at any of the rivers. More detailed spatial analysis including extent and thickness of the riparian strips might help to understand this better.

Our analysis is a first step in better understanding processes that drive trace elements concentrations and trace elements retention in the Swedish landscape. Many of the trace elements studied here are co-transported with organic matter, and a better understanding of quantitative organic carbon, $\mathrm{Al}$ and $\mathrm{Fe}$ removal in stream reaches and lakes will aid in the understanding of the fate of many trace elements, e.g. the systematic study of the transformation conditions of dissolved to particulate forms of $\mathrm{Al}$ and $\mathrm{Fe}$ such as described in Sjöstedt et al. (2010). Both systematic studies of temporal and spatial variation of filtered and unfiltered trace element concentrations (Huser et al., 2012) and speciation modelling of trace elements are under way to better elucidate trace element removal processes. Reasonable data for natural background concentrations of a large number of elements is required by the EU Water Framework Directive. Defining reliable background concentrations based on geographical information only seems a very challenging task. Our analysis implies that lake position, morphology and volume are the most important drivers for trace elements concentration as compared to many other natural landscape features in the investigated catchments.

\section{Conclusions}

The main hypothesis in this study was that trace elements and TOC (as well as $\mathrm{Al}$ and $\mathrm{Fe}$ ) show the same general pattern of catchment outputs and downstream changes. Common factor analysis revealed that this seems to hold true for $\mathrm{As}, \mathrm{Be}, \mathrm{Bi}$, $\mathrm{Cd}, \mathrm{Cr}, \mathrm{Ga}, \mathrm{Ge}, \mathrm{Pb}, \mathrm{Tl}, \mathrm{U}, \mathrm{V}$ and $\mathrm{Zn}$, as they usually co-vary positively with $\mathrm{Al}, \mathrm{Fe}$ and $\mathrm{TOC}$, and negatively with $\mathrm{La}, \mathrm{Li}$, $\mathrm{pH}$ and Sr. Hypothesis (1) did not seem to hold true for Ba, $\mathrm{Cu}, \mathrm{Mo}$ and $\mathrm{Sn}$. The other trace elements did not show the same clear pattern. As we speculated in the Introduction, hypothesis (2), many trace elements behaved similarly in those spatial patterns. The largest differences, both in number and magnitude, were observed when comparing the lake inlets with their outlets, with lower concentrations of $\mathrm{As}, \mathrm{Ba}, \mathrm{Be}$, $\mathrm{Bi}, \mathrm{Cd}, \mathrm{Co}, \mathrm{Cr}, \mathrm{Ga}, \mathrm{Ge}, \mathrm{Ni}, \mathrm{Pb}, \mathrm{Sn}, \mathrm{Ti}, \mathrm{Tl}, \mathrm{U}, \mathrm{V}$ and $\mathrm{Zn}$ at the lake outlets. The strong removal of a large number of trace elements when passing through lakes is evident in the FA analysis where lake surface coverage plots opposite to many of those elements. Forest coverage/volume did usually not correspond in a similar systematic fashion, and, surprisingly, the amount of wetland did not relate strongly to $\mathrm{Al}, \mathrm{Fe}$, TOC or most trace elements at any of the rivers. With regards to hypothesis (3), the elements $\mathrm{Cu}, \mathrm{Pb}$ and $\mathrm{Zn}$ appear prone to mobilisation in acidified environments rich in $\mathrm{SO}_{4}$ or under acidic conditions, while this does not seem to be the case for $\mathrm{Co}$ and $\mathrm{Ni}$.

Acknowledgements. Financial support for this research was provided by the Swedish University of Agricultural Sciences, the Swedish Environmental Protection Agency, and for Johan Temnerud also by the Knowledge Foundation and the Swedish Meteorological and Hydrological Institute. We thank our fellow collaborators for excellent field- and laboratory work: Jan-Olov Johansson, Kaloyan Kenov and Fredrik Pilström. Jakob Nisell and Fredrik Pilström are acknowledged for their valuable GIS-work. We thank the laboratory personal at the Department of Geological Sciences, Stockholm University, and at Vattenlaboratoriet, Uppsala Municipality. We thank Brian Huser for valuable comments on earlier drafts of this manuscript and also for October 1996-2009 data, and Martin Erlandsson for metaMAGIC simulations.

Edited by: N. Ohte

\section{References}

Alexander, R. B., Boyer, E. W., Smith, R. A., Schwarz, G. E., and Moore, R. B.: The role of headwater streams in downstream water quality, JAWRA, 43, 41-59, doi:10.1111/j.17521688.2007.00005.x, 2007.

Andersson, K., Dahlqvist, R., Turner, D., Stolpe, B., Larsson, T., Ingri, J., and Andersson, P.: Colloidal rare earth elements in a boreal river: Changing sources and distributions during the spring flood, Geochim. Cosmochim. Acta, 70, 3261-3274, doi:10.1016/j.gca.2006.04.021, 2006.

Bishop, K., Buffam, I., Erlandsson, M., Fölster, J., Laudon, H., Seibert, J., and Temnerud, J.: Aqua Incognita: the unknown headwaters, Hydrol. Process., 22, 1239-1242, doi:10.1002/hyp.7049, 2008.

Bresnahan, W. T., Grant, C. L., and Weber, J. H.: Stability constants for the complexation of copper(II) ions with water and soil fulvic acids measured by an ion selective electrode, Anal. Chem., 50, 1675-1679, doi:10.1021/ac50034a026, 1978.

Buffam, I., Laudon, H., Temnerud, J., Mörth, C.-M., and Bishop, K.: Landscape-scale variability of acidity and dissolved organic carbon during spring flood in a boreal stream network, J. Geophys. Res.-Biogeosci., 112, G01022, doi:10.1029/2006JG000218, 2007.

Costello, A. B. and Osborne, J. W.: Best practices in exploratory factor analysis: Four recommendations for getting the most from your analysis, Practical Assessment, Res. Evaluat., 10, 1-9, http: //pareonline.net/pdf/v10n7.pdf, 2005.

Dahlqvist, R., Andersson, K., Ingri, J., Larsson, T., Stolpe, B., and Turner, D.: Temporal variations of colloidal carrier phases and associated trace elements in a boreal river, Geochim. Cosmochim. Acta, 71, 5339-5354, doi:10.1016/j.gca.2007.09.016, 2007.

Drever, J. I.: The Geochemistry of Natural Waters: Surface and Groundwater Environments., 3 Edn., Prentice-Hall, Upper Saddle River, USA, 436 pp., 1997. 
Edén, P., Weppling, K., and Jokela, S.: Natural and land-use induced load of acidity, metals, humus and suspended matter in Lestijoki, a river in western Finland, Boreal Environ. Res., 4, 31-43, http: //www.borenv.net/BER/pdfs/ber4/ber4-031-043.pdf, 1999.

EEA: CORINE (Coordination of information on the environment): http://www.eea.europa.eu/publications/COR0-landcover, 2002.

Egeberg, P. K. and Håkedal, J. T.: The effect of river liming on the trace metal budgets of a down stream lake, Water Air Soil Pollut., 104, 57-75, doi:10.1023/a:1004955216612, 1998.

Ejhed, H., Karlsson, M., Köhler, S., Malm, J., Gustavsson, H., and Westerberg, I.: Nettobelastning av metaller i Dalälven (Net load of metals in the River Dalälven, in Swedish with an English summary), SMHI, Norrköping, SMED Report no. 104, http://www.smed.se/wp-content/uploads/2012/08/ SMED_Rapport_2012_1041.pdf, 84 pp., 2012.

Engström, E., Rodushkin, I., Ingri, J., Baxter, D. C., Ecke, F., Österlund, H., and Öhlander, B.: Temporal isotopic variations of dissolved silicon in a pristine boreal river, Chem. Geol., 271, 142-152, doi:10.1016/j.chemgeo.2010.01.005, 2010.

Erlandsson, M., Fölster, J., Wilander, A., and Bishop, K.: A metamodel based on MAGIC to predict the pre-industrial acidity status of surface waters, Aquat. Sci., 70, 238-247, doi:10.1007/s00027-008-8018-0, 2008.

Fölster, J., Köhler, S., von Brömssen, C., Akselsson, C., and Rönnback, P.: Korrigering av vattenkemi för kalkningspåverkan. Val av referenser och beräkning av osäkerheter (Correction of water chemistry for liming effect. Selection of references and calculation of uncertainties, in Swedish with an English summary), Swedish University of Agricultural Sciences, Uppsala, Report 2011:1, http://publikationer.slu.se/Filer/ Rapport20111CaMg.pdf, 71 pp., 2011.

Gadmar, T. C., Vogt, R. D., and Østerhus, B.: The merits of the high temperature combustion method for determining the amount of natural organic carbon in surface freshwater samples, Intern. J. Environ. Anal. Chem., 82, 451-461, doi:10.1080/0306731021000018099, 2002.

Gauch Jr., H. G.,: Multivariate Analysis in Community Ecology, Cambridge studies in ecology; 1, Cambridge University Press, Cambridge, UK, 298 pp., 1982.

Grahn, E., Karlsson, S., Karlsson, U., and Düker, A.: Historical pollution of seldom monitored trace elements in Sweden - Part B: Sediment analysis of silver, antimony, thallium and indium, J. Environ. Monit., 8, 732-744, doi:10.1039/B601948J, 2006.

Hart, B. T.: Trace metal complexing capacity of natural waters: A review, Environ. Technol. Lett., 2, 95-110, doi:10.1080/09593338109384029, 1981.

Honeyman, B. D. and Santschi, P. H.: Metals in aquatic systems, Environ. Sci. Technol., 22, 862-871, doi:10.1021/es00173a002, 1988.

Huser, B. J., Köhler, S. J., Wilander, A., Johansson, K., and Fölster, J.: Temporal and spatial trends for trace metals in streams and rivers across Sweden (1996-2009), Biogeosciences, 8, 18131823, doi:10.5194/bg-8-1813-2011, 2011.

Huser, B. J., Fölster, J., and Köhler, S.: Lead, zinc, and chromium concentrations in acidic headwater streams in Sweden explained by chemical, climatic, and land-use variations, Biogeosciences, 9, 4323-4335, doi:10.5194/bg-9-4323-2012, 2012.

Hutchins, M. G., Smith, B., Rawlins, B. G., and Lister, T. R.: Temporal and spatial variability of stream waters in Wales, the
Welsh borders and part of the West Midlands, UK 1, Major ion concentrations, Wat. Res., 33, 3479-3491, doi:10.1016/S00431354(99)00057-3, 1999.

Ivarsson, H. and Jansson, M.: Regional variation of dissolved organic matter in running waters in central northern Sweden, Hydrobiologia, 286, 37-51, doi:10.1007/BF00007279, 1994.

Johannesson, K. H., Tang, J., Daniels, J. M., Bounds, W. J., and Burdige, D. J.: Rare earth element concentrations and speciation in organic-rich blackwaters of the Great Dismal Swamp, Virginia, USA, Chem. Geol., 209, 271-294, doi:10.1016/j.chemgeo.2004.06.012, 2004.

Johansson, H., Lindström, M., and Håkanson, L.: On the modelling of the particulate and dissolved fractions of substances in aquatic ecosystems - sedimentological and ecological interactions, Ecol. Model., 137, 225-240, doi:10.1016/S03043800(00)00439-7, 2001.

Karlsson, S., Grahn, E., Düker, A., and Bäckström, M.: Historical pollution of seldom monitored trace elements in Sweden Part A, J. Environ. Monit., 8, 721-731, doi:10.1039/B601944G, 2006.

Köhler, S.: Quantifying the role of natural organic acids on $\mathrm{pH}$ and buffering in Swedish surface waters, Doctoral Thesis, Forest Ecology, Swedish University of Agricultural Sciences, Umeå, Sweden, 163 pp., 1999.

Köhler, S.: Comparing filtered and unfiltered metal concentrations in some Swedish surface waters, Swedish University of Agricultural Sciences, Uppsala, Report 2010:04, http://publikationer.slu. se/Filer/Metalsreportfinal.pdf, 59 pp., 2010.

Köhler, S., Laudon, H., Wilander, A., and Bishop, K.: Estimating organic acid dissociation in natural surface waters using total alkalinity and TOC, Wat. Res., 34, 1425-1434, doi:10.1016/S00431354(99)00315-2, 2000.

Köhler, S., Löfgren, S., Wilander, A., and Bishop, K.: Validating a simple equation to predict and analyze organic anion charge in Swedish low ionic strength surface waters, Water Air Soil Pollut., 130, 799-804, doi:10.1023/A:1013810324218, 2001.

Köhler, S., Zetterberg, T., Futter, M., Fölster, J., and Löfgren, S.: Assessment of uncertainty in long-term mass balances for acidification assessments: A MAGIC model exercise, Ambio, 40, 891905, doi:10.1007/s13280-011-0208-7, 2011.

Lawlor, A. J. and Tipping, E.: Metals in bulk deposition and surface waters at two upland locations in northern England, Environ. Pollut., 121, 153-167, doi:10.1016/S0269-7491(02)00228-2, 2003.

Lax, K.: Environmental applications of biogeochemical data from Geological Survey of Sweden, Licentiate, Department of Civil, Environmental and Natural Resources Engineering, Luleå University of Technology, Luleå, http://pure.ltu.se/portal/files/ 191070/LTU-LIC-0595-SE.pdf, 97 pp., 2005.

Lax, K., Edén, P., and Björklund, A.: Wide-spaced sampling of humus in Fennoscandia, J. Geochem. Explor., 55, 151-161, doi:10.1016/0375-6742(95)00019-4, 1995.

Lidman, F., Mörth, C. M., and Laudon, H.: Landscape control of uranium and thorium in boreal streams - spatiotemporal variability and the role of wetlands, Biogeosciences, 9, 4773-4785, doi:10.5194/bg-9-4773-2012, 2012.

Likens, G. E. and Buso, D. C.: Variation in streamwater chemistry throughout the Hubbard Brook Valley, Biogeochem., 78, 1-30, doi:10.1007/s10533-005-2024-2, 2006. 
Lindström, G., Pers, C., Rosberg, J., Strömqvist, J., and Arheimer, B.: Development and test of the HYPE (Hydrological Predictions for the Environment) model - A water quality model for different spatial scales, Hydrol. Res., 41, 295-319, doi:10.2166/nh.2010.007, 2010.

Löfgren, S., Aastrup, M., Bringmark, L., Hultberg, H., LewinPihlblad, L., Lundin, L., Karlsson, G. P., and Thunholm, B.: Recovery of soil water, groundwater, and streamwater from acidification at the Swedish Integrated Monitoring catchments, Ambio, 40, 836-856, doi:10.1007/s13280-011-0207-8, 2011.

Lofts, S. and Tipping, E.: Solid-solution metal partitioning in the Humber rivers: application of WHAM and SCAMP, Sci. Total Environ., 251, 381-399, doi:10.1016/S0048-9697(00)00418-6, 2000.

Lowe, W. H. and Likens, G. E.: Moving headwater streams to the head of the class, Bioscience, 55, 196-197, doi:10.1641/00063568(2005)055[0196:MHSTTH]2.0.CO;2, 2005.

Lydersen, E., Löfgren, S., and Arnesen, R. T.: Metals in Scandinavian surface waters: Effects of acidification, liming, and potential reacidification, Critical Reviews in Environmental Science and Technology, 32, 73-295, doi:10.1080/10643380290813453, 2002.

Lyvén, B., Hassellöv, M., Turner, D. R., Haraldsson, C., and Andersson, K.: Competition between iron- and carbon-based colloidal carriers for trace metals in a freshwater assessed using flow fieldflow fractionation coupled to ICPMS, Geochim. Cosmochim. Acta, 67, 3791-3802, doi:10.1016/S0016-7037(03)00087-5, 2003.

Meili, M.: Sources, concentrations and characteristics of organic matter in softwater lakes and streams of the Swedish forest region, Hydrobiologia, 229, 23-41, doi:10.1007/BF00006988, 1992.

Moldan, F., Kronnäs, V., Wilander, A., Karltun, E., and Cosby, B. J.: Modelling acidification and recovery of Swedish lakes, Water Air Soil Pollut., 4, 139-160, doi:10.1023/b:wafo.0000028351.14511.66, 2004.

Nagorski, S. A., Moore, J. N., McKinnon, T. E., and Smith, D. B.: Scale-dependent temporal variations in stream water geochemistry, Environ. Sci. Technol., 37, 859-864, doi:10.1021/es025983+, 2003.

Nisell, J., Lindsjö, A., and Temnerud, J.: Rikstäckande virtuellt vattendrags nätverk för flödesbaserad modellering VIVAN. Utveckling av anpassade geografiska data för hydrologiska och vattenkemiska tillämpningar (VIVAN: Nationwide virtual network of watercourses for flow-based modelling, Development of customized geographic data for applications in hydrology and aqueous chemistry, in Swedish with an English summary), Swedish University of Agricultural Sciences, Uppsala, Report 2007:17, http://publikationer.slu.se/Filer/VIVAN_2007-17. pdf, 21 pp.,2007.

Piper, A. M.: A graphic procedure in the geochemical interpretation of water analysis, Trans. Am. Geophys. Union, 25, 914-923, 1944.

Pokrovsky, O. S., Shirokova, L. S., Kirpotin, S. N., Audry, S., Viers, J., and Dupre, B.: Effect of permafrost thawing on organic carbon and trace element colloidal speciation in the thermokarst lakes of western Siberia, Biogeosciences, 8, 565-583, doi:10.5194/bg-8565-2011, 2011.
PTA: Guide to Proficiency Testing Australia, Proficiency Testing Australia, Silverwater, Australia, 27 pp., 2006.

Reese, H., Nilsson, M., Granqvist Pahlén, T., Hagner, O., Joyce, S., Tingelöf, U., Egberth, M., and Olsson, H.: Countrywide estimates of forest variables using satellite data and field data from the national forest inventory, Ambio, 33, 542-548, doi:10.1579/0044-7447-32.8.542, 2003.

Reimann, C., Finne, T. E., Nordgulen, Ø., Sæther, O. M., Arnoldussen, A., and Banks, D.: The influence of geology and land-use on inorganic stream water quality in the Oslo region, Norway, Appl. Geochem., 24, 1862-1874, doi:10.1016/j.apgeochem.2009.06.007, 2009.

Ross, J. M. and Sherrell, R. M.: The role of colloids in tracemetal transport and adsorption behavior in New Jersey Pinelands streams, Limnol. Oceanogr., 44, 1019-1034, doi:10.4319/lo.1999.44.4.1019, 1999.

Salminen, R., (Chief-editor), Batista, M. J., Bidovec, M., Demetriades, A., De Vivo, B., De Vos, W., Duris, M., Gilucis, A., Gregorauskiene, V., Halamic, J., Heitzmann, P., Lima, A., Jordan, G., Klaver, G., Klein, P., Lis, J., Locutura, J., Marsina, K., Mazreku, A., O'Connor, P. J., Olsson, S. Å., Ottesen, R.-T., Petersell, V., Plant, J. A., Reeder, S., Salpeteur, I., Sandström, H., Siewers, U., Steenfelt, A., and Tarvainen, T.: Geochemical Atlas of Europe. Part 1 - Background Information, Methodology and Maps, Last checked 13 April 2011 http://weppi.gtk.fi/publ/foregsatlas/ articles/Statistics.pdf, 2005.

SEPA: Bedömningsgrunder för miljökvalitet. Sjöar och vattendrag, Bakgrundsrapport 1: Kemiska och fysikaliska parametrar (Environmental quality criteria, Lakes and watercourses, Background report 1, Chemical and physical parameters, in Swedish with an English summary), Swedish Environmental Protection Agency, Stockholm, Report 4920, 205 pp., 1999.

SGU: Soil map, 1 : 50000, The Geological Survey of Sweden, Uppsala, 2001.

SGU: The level of groundwatertable in Sweden during October 2007 (map with Swedish text): http://www.sgu.se/sgu/sv/ samhalle/grundvatten/grundvattennivaer/2007/okt07.html, 2012.

Sholkovitz, E. R.: Chemical evolution of rare earth elements: fractionation between colloidal and solution phases of filtered river water, Earth Planet. Sci. Lett., 114, 77-84, doi:10.1016/0012821x(92)90152-1, 1992.

Sjöstedt, C. S., Gustafsson, J. P., and Köhler, S. J.: Chemical equilibrium modeling of organic acids, $\mathrm{pH}$, aluminum, and iron in Swedish surface waters, Environ. Sci. Technol., 44, 8587-8593, doi:10.1021/es102415r, 2010.

Smart, R. P., Soulsby, C., Cresser, M. S., Wade, A. J., Townend, J., Billett, M. F., and Langan, S.: Riparian zone influence on stream water chemistry at different spatial scales: a GIS-based modelling approach, an example for the Dee, NE Scotland, Sci. Total Environ., 280, 173-193, doi:10.1016/S0048-9697(01)00824$5,2001$.

SMHI: The monthly weather in Sweden in September and October 2007 (maps with Swedish text): http://www.smhi.se/klimatdata/Manadens-vader-och-vatten/ Sverige/oktober-2007-temperatur-och-nederbord-1.4779 and http://www.smhi.se/klimatdata/Manadens-vader-och-vatten/ Sverige/september-2007-temperatur-och-nederbord-1.4758, 2012. 
SNLS: Land-use map, scale $1: 20000$, The Swedish National Land Survey, Gävle, 2002.

Stumm, W.: Chemistry of the Solid-Water Interface: Processes at the Mineral-Water and Particle-Water Interface in Natural Systems, John Wiley, New York, USA, 428 pp., 1992.

Stumm, W. and Morgan, J. J.: Aquatic Chemistry: Chemical Equilibria and Rates in Natural Waters., 3 Edn., John Wiley, New York, USA, p. 272, p. 293, 1996.

Taillefert, M. and Gaillard, J. F.: Reactive transport modeling of trace elements in the water column of a stratified lake: iron cycling and metal scavenging, J. Hydrol., 256, 16-34, doi:10.1016/s0022-1694(01)00524-8, 2002.

Tarvainen, T., Lahermo, P., and Mannio, J.: Sources of trace metals in streams and headwater lakes in Finland, Water Air Soil Pollut., 94, 1-32, doi:10.1007/BF02407090, 1997.

Temnerud, J. and Bishop, K.: Spatial variation of streamwater chemistry in two Swedish boreal catchments: Implications for environmental assessment, Environ. Sci. Technol., 39, 14631469, doi:10.1021/es040045q, 2005.

Temnerud, J., Fölster, J., Pilström, F., and Bishop, K.: Synoptisk provtagning av små vattendrag i södra Sverige oktober 2007 (Synoptical sampling of small watercourses in southern Sweden in October 2007, in Swedish), Swedish University of Agricultural Sciences, Uppsala, Report 2009:6, http://publikationer.slu. se/Filer/Rapport2009-6.pdf, 56 pp., 2009.
Tipping, E., Rothwell, J. J., Shotbolt, L., and Lawlor, A. J.: Dynamic modelling of atmospherically-deposited $\mathrm{Ni}, \mathrm{Cu}, \mathrm{Zn}, \mathrm{Cd}$ and $\mathrm{Pb}$ in Pennine catchments (northern England), Environ. Pollut., 158, 1521-1529, doi:10.1016/j.envpol.2009.12.026, 2010.

von Wachenfeldt, E., and Tranvik, L.: Sedimentation in boreal lakes. The role of flocculation of allochthonous dissolved organic matter in the water column, Ecosystems, 11, 803-814, doi:10.1007/s10021-008-9162-z, 2008.

Wällstedt, T., Björkvald, L., and Gustafsson, J. P.: Increasing concentrations of arsenic and vanadium in (southern) Swedish streams, Appl. Geochem., 25, 1162-1175, doi:10.1016/j.apgeochem.2010.05.002, 2010.

Winston, R. B.: Graphical User Interface for MODFLOW, Version 4, U.S. Geological Survey, Open-File Report 00-315, http: //water.usgs.gov/nrp/gwsoftware/GW_Chart/GW_Chart.html, 27 pp., 2000.

Wolock, D. M., Fan, J., and Lawrence, G. B.: Effects on basin size on low-flow stream chemistry and subsurface contact time in the Neversink river watershed, New York, Hydrol. Process., 11, 1273-1286, doi:10.1002/(SICI)10991085(199707)11:9¡1273::AID-HYP557¡3.0.CO;2-S, 1997. 